\title{
SOLAR PHOTOVOLTAIC/THERMAL RESIDENTIAL SYSTEMS
}

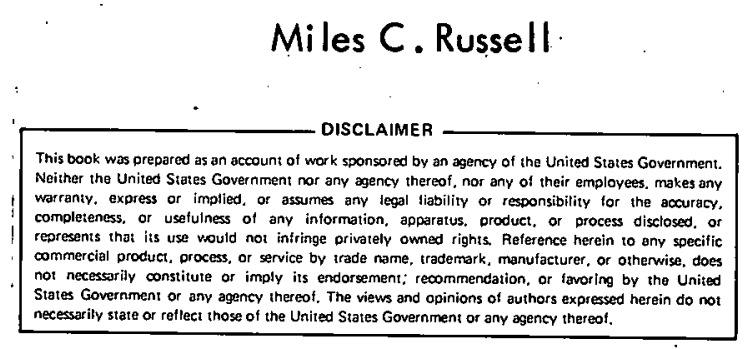

28 December 1979

Massachusetts Institute of Technology

Lincoln Laboratory

Lexington, Massachusetts 02173

Prepared for the

U.S. DEPARTMENT OF ENERGY

UNDER CONTRACT NO. EY-77-S-02-4577 


\section{DISCLAIMER}

This report was prepared as an account of work sponsored by an agency of the United States Government. Neither the United States Government nor any agency Thereof, nor any of their employees, makes any warranty, express or implied, or assumes any legal liability or responsibility for the accuracy, completeness, or usefulness of any information, apparatus, product, or process disclosed, or represents that its use would not infringe privately owned rights. Reference herein to any specific commercial product, process, or service by trade name, trademark, manufacturer, or otherwise does not necessarily constitute or imply its endorsement, recommendation, or favoring by the United States Government or any agency thereof. The views and opinions of authors expressed herein do not necessarily state or reflect those of the United States Government or any agency thereof. 


\section{DISCLAIMER}

Portions of this document may be illegible in electronic image products. Images are produced from the best available original document. 
This report presents the results of a conceptual design study using computer simulations to determine the physical and economic performance of combined photovoltaic/thermal collector heat-pump. solar systems for a singlefamily. residence. Economic analyses are based upon projected costs for a 1986 system installation. The results show that $\mathrm{PV} / \mathrm{T}$ collector systems can be economically competitive for a cold climate residence, that systems employing on-site electrical storage batteries are not economically competitive with utility-interactive systems, and that an ambient-air-source heat-pump system has a lower life-cycle cost than a solar-source heat-pump system. 
This report presents the results of a conceptual design study using computer simulations to determine the physical and economic performance of combined photovoltaic/thermal collector heat-pump solar systems for a singlefamily residence. Economic analyses are based upon projected costs for a 1986 system installation. The results show that $\mathrm{PV} / \mathrm{T}$ collector systems can be economically competitive for a cold climate residence, that systems employing on-site electrical storage batteries are not economically competitive with utility-interactive systems, and that an ambient-air-source heat-pump system has a lower life-cycle cost than a solar-source heat-pump system. 


\section{TABLE OF CONTENTS}

$\underline{\text { Section }}$

$\underline{\text { Page }}$

Abstract

iii

List of Figures

vii

List of Tables'..

viii

1.0 INTRODUCTION

1.1 Objectives

1.2 Summary and Conclusions

2.0

ANALYSIS METHODOLOGY. . . . 3

2.1. Meterological:and Heating/Cooling Data 3

2.2 Residential Loads 6

2.3 Residential Energy System Concepts 7

2.3.1 Series or Solar-Source Heat-Pump Thermal 9 Subsystem

2.3.2 Parallel or Ambient-Air-Source Heat-Pump II Thermal Subsystem

2.3.3 Utility-Interactive Inverter Electrical 12 Subsystem

2.3.4 DC Electrical Subsystem with Storage 12

2. 4 Component Models $\quad 12$

2.4.1 Heat Pumps 14

2.4.2 Photovoltaic/Thermal Collector 16

2.4.3 Electrical Subsystem Components $\quad 18$

2.4.4. Thermal Subsystem Components 18

2.5 Economic Analysis 18

3.0 RESULTS 25

3.1 New York Residence System Performance Results 25

3.2 New York Residence System Economic Forecasts 28

3.3 Fort Worth Sy stem Performance. Results 32

3.4. Fort Worth Residence System Economic Forecasts 33

4.0 CONCLUSIONS $\quad 35$ 
TABLE OF CONTENTS (CONTINUED)

Section

Page

5:0 HARDWARE CONSIDERATIONS

5.1 Constraints on System Complexity $\quad 36$

5. 2 Hardware Availability and Cost 39

5.3. Carrier Corporation's "Solaround" System 39

5.3.1 Variable-Speed Compressor 39

5.3.2 Collector Fluid 40

5.3.3 Tri-X Coil 40

5.3.4 Desuperheating of the Compressor's Discharge 42 Line

5.3.5 Resistance Heating $\cdot 42$

5.4 Modified Solaround System Inventory 43

5.5 Combined Photovoltaic/Thermal Collectors 45

REFERENCES 
1. Meteorological and Residential Space, Conditioning Load Quantities on Magnetic Tape

Residential Heating and Cooling Demand

3 Month1y Supply Water Temperature

4. Combined Photovoltaic/Thermal Collector Performance Characteristics

System Economic Assumptions

7 Energy Performance of a New York Residence Utilizing Separate Photovoltaic and Thermal Collectors

8 Levelized Annual Cost of a New York Residence Utilizing Separate Photovoltaic and Thermal Collectors

9 Energy Performance of a Fort Worth Residence Utilizing Separate Photovoltaic and Thermal Collectors

10 Levelized Annual Cost of a Fort Worth Residence Utilizing Separate Photovoltaic and Thermal Collectors

11 Carrier Corporation Components Included in PV/T Prototype System 
1 Procedure flowchart 4

Domestic hot water demand profile

Diversified electric power demand profile

Series heat-pump thermal subsystem block diagram : 10

Series heat-pump thermal subsystem control strategy

Parallel heat-pump thermal subsystem block diagram 11

Parallel heat-pump thermal subsystem control strategy

Utility-interactive inverter electrical subsystem block diagram

DC electrical subsystem with storage block diagram 13

New York residence (w1th utility-interactive electrical subsystem) system performance results

16 New York residence (with DC electrical subsystem with storage) system performance results

New York residence (with utility-interactive electrical subsystem) system economic forecasts

New York residence (with DC electrical subsystem with storage) system economic forecasts

New York residence system economic forecasts for separate thermal and photovoltalc collector systems

Fort Worth residence system: performance results

Fort Worth residence system economic forecasts

Series heat-pump configuration with preheating of return air

Parallel heat-pump configuration with preheating of return air

Dual-mode heat-pump configuration with preheating of return air 
Since October 1977, MIT Lincoln Laboratory has been researching combined photovoltaic/thermal (PV/T) solar collectors to assess their potential for use in meeting residential energy demands. This report presents the results of a conceptual design study using computer simulations to determine the physical and economic performance of the most desirable PV/T collector heat-pump solai. systems for a single-family residence.

\section{1 objectives}

The objectives of this design study were:

- To identify. "reasonable" residential PV/T heat-pump system configurations.

- To predict the performance of such systems in meeting residential heating, cooling and electric power demands.

- To compare system performances in northern and southern climates.

- To determine the most desirable systems for each of the two climates.

All economic evaluations were based on anticipated mid-1980's photovoltaic technology and prices and on 1986 system installation.

\subsection{Summary and Conclusions.}

The TRNSYS simulation program, developed by the University of Wisconsin, was used to predict system energy flows in PV/T heat-pump systems in both New York and Fort Worth. The total auxillary energy required by each system to meet the annual residential space heating, space cooling, hot water and diversified electric loads was calculated.

Two thermal subsystems were studied: a series or solar-source heat pump and a parallel or ambient-air-source heat pump. Two electric subsystems were studied: a utility-interactive DC-AC inverter subsystem which channels solar energy in excess of instantaneous on-site demands to the utility, and a DC subsystem with on-site electric energy storage and a "consume-only" utility connection. Four systems may be configured by permuting these thermal and electrical subsystems. The primary independent variable in all four systems, the total collector area, was varied from 0 to 100 square meters. 
Economic analyses used TRNSYS performance results and assumptions for component costs, mortgage rates, tax marginal brackets, general inflation rate, energy escalation rate, and tax incentives to calculate the predicted levelized annual cost of owning and operating the solar system for its assumed 20-year lifetime beginning in 1986.

The results of this study show that:

- Systems employing on-site electrical storage batteries are not economically competitive with utility-interactive systems for a 0.5 utflity energy buy-to-sell ratio.

- For the New York (northern) residence, the parallel heat-pump system. configuration meets a greater percentage of the total residential loads with solar energy than the series heat-pump configuration for $\mathrm{PV} / \mathrm{T}$ collector areas less than $\sim 75$ square meters.

- A parallel heat-pump system ut1lizing 40 square meters of $\mathrm{PV} / \mathrm{T}$ collectors and providing $45 \%$ of the total residential energy demands represents the most economical $\mathrm{PV} / \mathrm{T}$ system option of those studied for the New York restdence.

- Separate thermal collectors and photovoltaic collectors result in systems with costs comparable to those using combined $\mathrm{PV} / \mathrm{T}$. collectors in the New York residence.

- Due to the availability of low-cost electrical energy during the heating season in the Fort Worth (southern) residence, $\mathrm{PV} / \mathrm{T}$ collector systems are not cost competitive in this location.

- The most economical system option for the Fort Worth residence consists of a parallel heat-pump. system with $\sim 35 \mathrm{~m}^{2}$ of photovoltaic collectors, which provides $\sim 48 \%$ of the total residential energy demands. 
Figure 1 illustrates the general procedure used to evaluate the residential systems considered in this study. Hourly meteorological data and hourly residential heating and cooling demands were obtained for locations representative of the northern and southern regions of the United States. These data are based upon SOLMET weather data. Characteristic domestic hot water and diversified electric power loads were also defined for each location.

Residential photovoltaic/thermal system concepts were identified and the TRNSYS program was used to predict each system's performance. Simulations utilized a one-year period of weather data and load information to calculate the total auxiliary energy required to meet the annual space heating, space cooling, domestic hot water and electric power demands of the residence. Systems with combined photovoltaic/thermal, simple photovoltaic and simple thermal collectors were considered. The primary independent variable in the study was the total collector area, which was varied from 0 to 100 square meters.

An economic analysis calculated the levelized annual cost of owning, operating and maintaining the photovoltaic power system. This quantity includes the costs of borrowed capital, operation and maintenance, and auxiliary energy. Assumptions were made for the homeowner's mortgage rate and tax bracket as well as for the general inflation rate and energy escalation rate. The component costs and performance assumed are consistent with United States Department of Energy goals for photovoltalc devices. The levelized annual system cost is based upon a 20-year system 1ifetime beginning in 1986. The ranking of system concepts was based upon the calculated levelized annual cost.

\subsection{Meteorological and Heating/Cooling Data}

The hourly solar and meteorological data used in this study are from SOLMET tapes for New York (1958) and Fort Worth (1960). Hourly space-conditioning loads were calculated for an $1800-\mathrm{ft}^{2}$ single-family detached residence using this weather data and the National Bureau of Standards Load Determination Program (NBSLD) (1). The loads and weather data, available on magnetic tape, are 1isted in Table 1. 


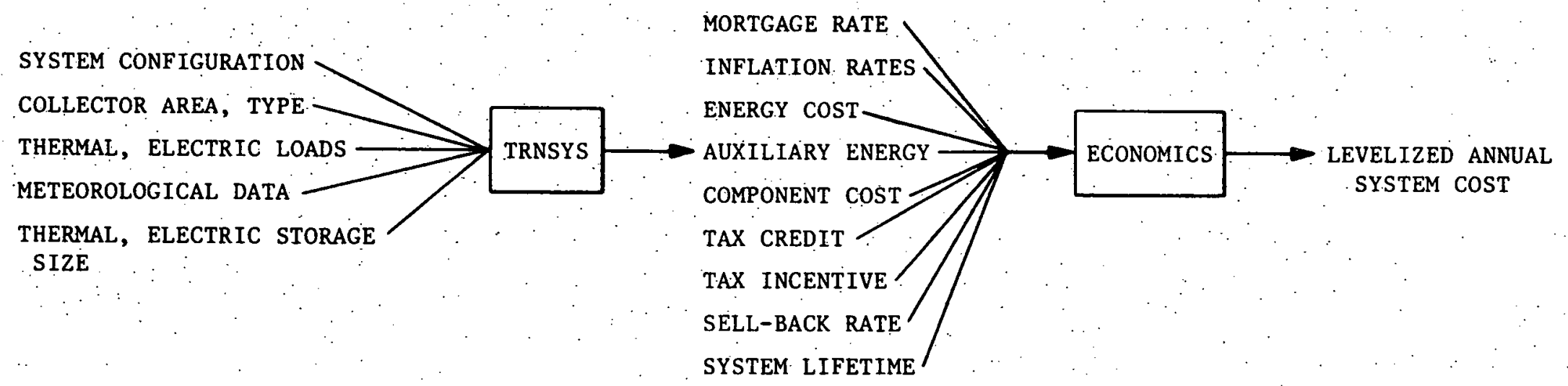

Figure 1. Procedure flowchart. 
TABLE 1

METEOROLOGICAL AND -RESIDENTIAL SPACE

CONDITIONING LOAD QUANTITIES ON MAGNETIC TAPE

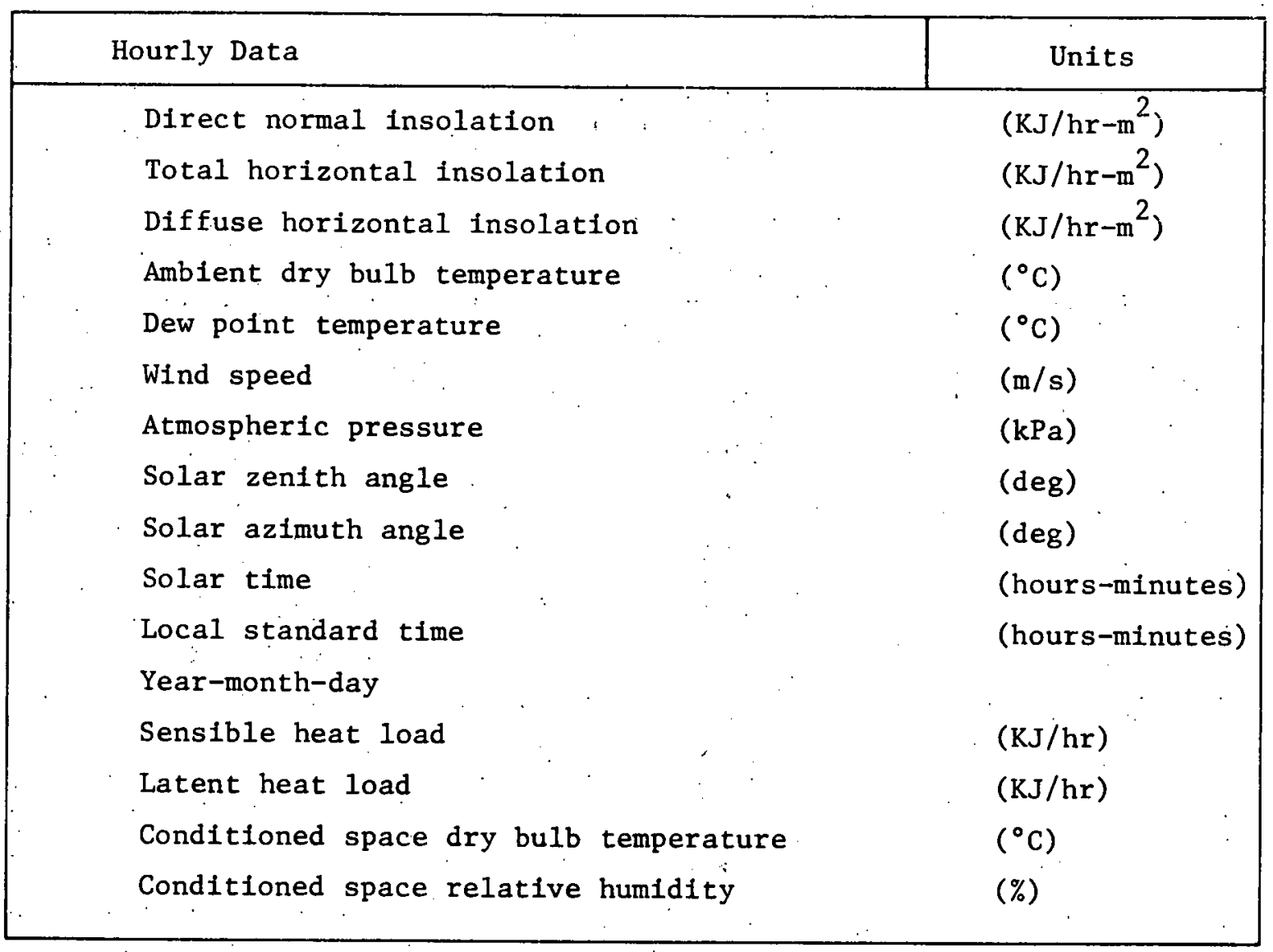


A summary of the monthly heating and cooling loads used in the system simulations is shown in Table 2 . The assumptions used in calculating the hourly space-conditioning loads resulted in a high annual heating load and a small cooling load for the New York residence: To obtain loads more Indicative of energy-consclentious construction, shown in Table 2 , the hourly heating loads from the data tape were halved and the cooling loads were doubled.

TABLE 2

RESIDENTIAL HEATING AND COOLING DEMAND

(kilowatt-hours thermal)

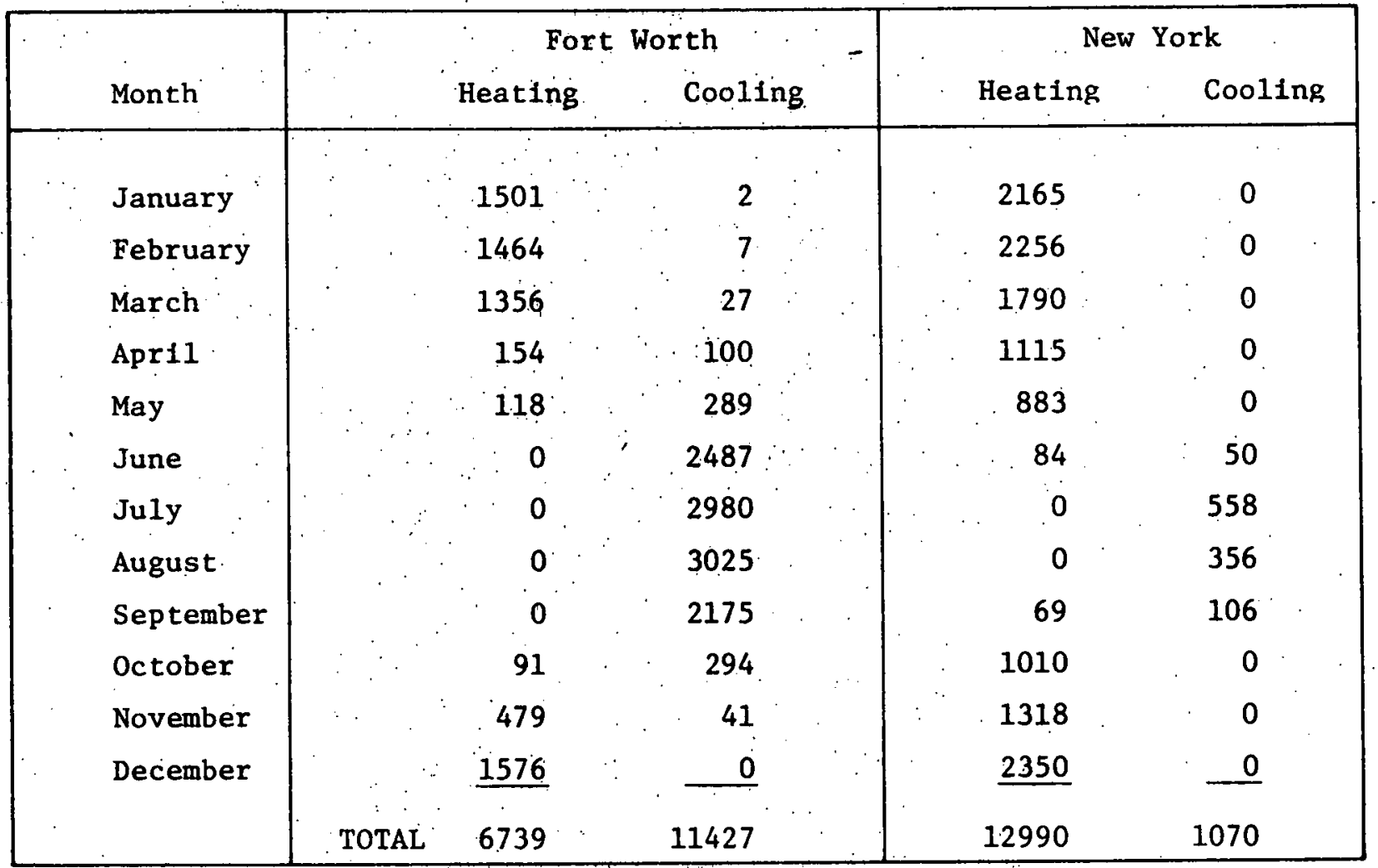

\subsection{Residential Loads}

The assumed hot water demand proflle adopted from Reference 2 is shown in Figure 2. A dally total of $227 \mathrm{kilograms}$ at $65^{\circ} \mathrm{C}$ is assumed for a four-person family. Due to seasonal temperature variations in the supply water, the energy 
Fig. 2. Domestic hot water demand profile.

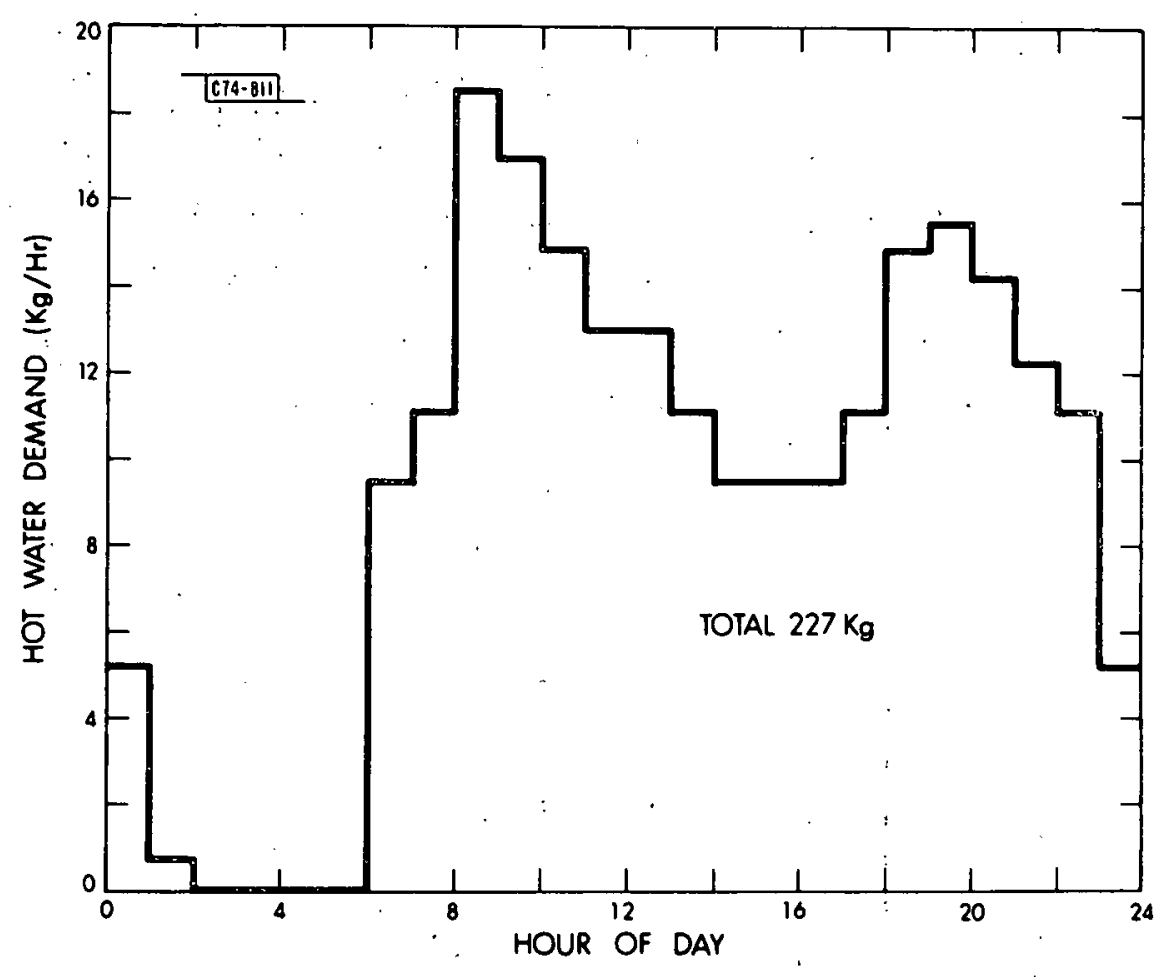

required to meet this demand changes. Table 3 shows the monthly supply water temperature assumed for the New York and Fort Worth locations.

A daily diversified (non-heating or cooling) electric power demand profile adopted from Reference 2 is shown in Figure 3. This load was assumed equal for both locations. A dally total of $26.7 \mathrm{kWh}$ is assumed for lights and appliances; no seasonal variation was assumed.

\subsection{Residential Energy System Concepts}

Photovoltaic/thermal collectors may be configured into a variety of residential energy systems by selecting different thermal and electrical subsystems. Two thermal subsystem heat pump configurations are of interest: a series or solar-source heat pump, and a parallel or ambient air-source heat pump. Two electrical subsystem options were considered: a utilityinteractive $\mathrm{DC}-$ to-AC power inverter with no on-site electrical storage, and a DC subsystem utilizing lead-acid batteries for storage. In addition to the four solar system options which may be configured by combining the'thermal and electrical subsystems, a non-solar or conventional system was simulated 
TABLE $\cdot 3$

MONTHLY SUPPLY WATER TEMPERATURE

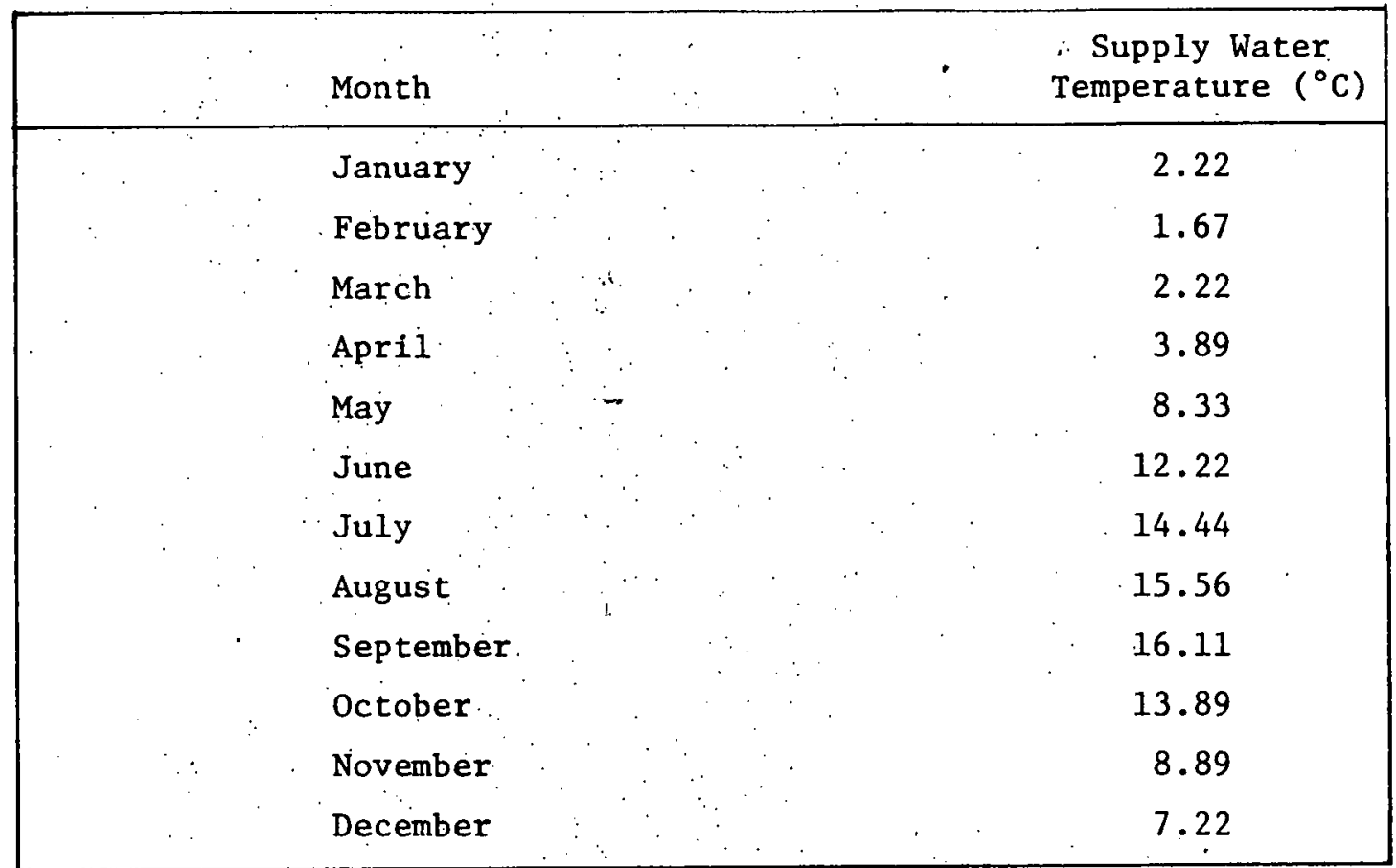

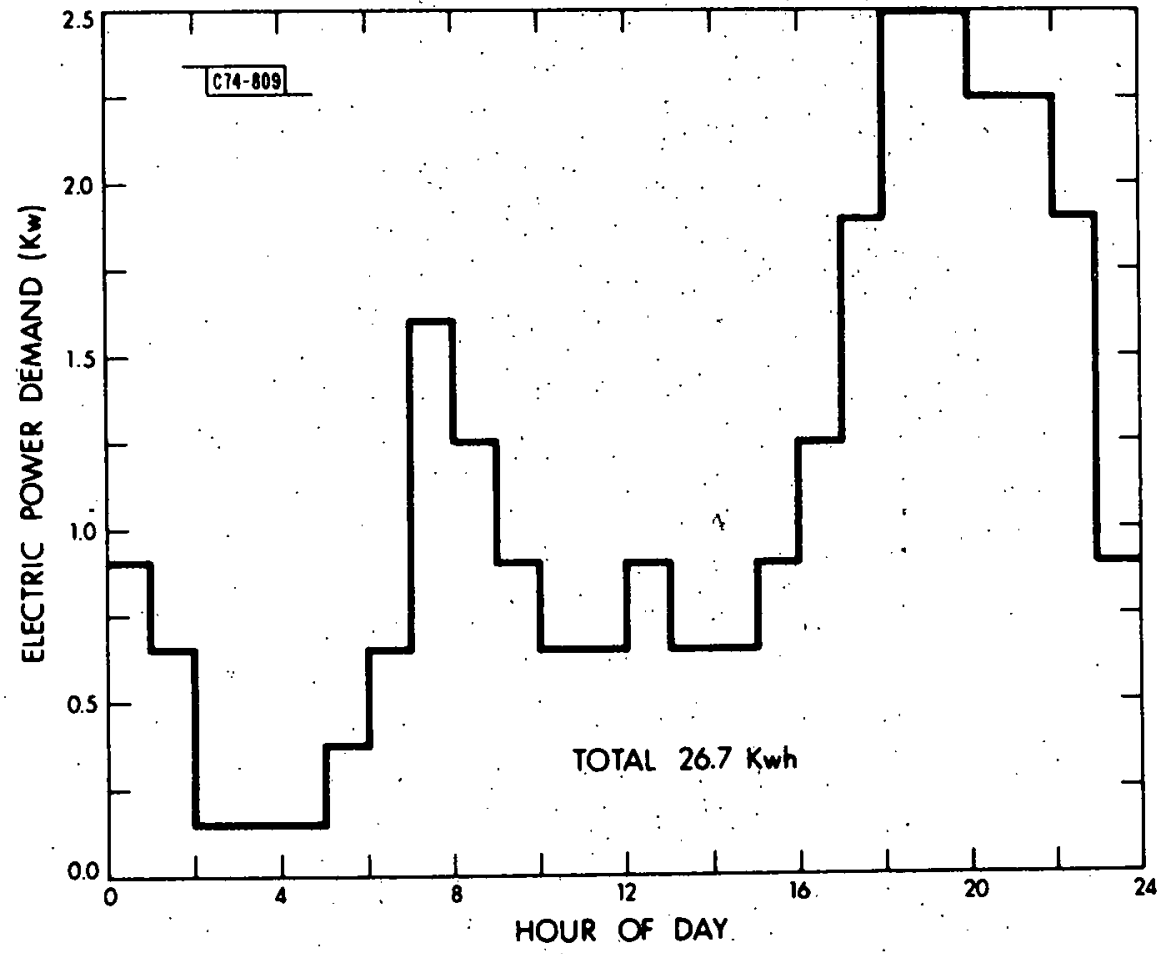

Fig. 3: Diversified elect ric power demand profile. 
for comparison. The conventional system consists of an ambient-air-source heat pump with electrical resistance heating as backup. The hot water is heated electrically.

A system consists of both electrical and thermal subsystems, and an array of photovoltaic/thermal collectors. For comparison, several simulations using arrays of separate photovoltaic and thermal collectors were made. The subsystems considered are described below.

2.3.1 Series, or Solar-Source; Heat-Pump Thermal Subsystem

A series heat pump is one which operates in the heating mode with thermal energy supplied to its evaporator by the solar thermal storage tank. The series subsystem is shown in Figure 4. The heat pump in this system is designed to operate with evaporator temperatures in the range of 0 to $40^{\circ} \mathrm{C}$.

Thermal energy from the combined photovoltaic/thermal collector array is stored in a water tank. When the storage temperature is above $40^{\circ} \mathrm{C}$, the water may be circulated through a heat exchanger in the room-return air duct to provide energy directly to the space-heating load. In this mode, the heat pump is bypassed and the system resembles a conventional solar-thermal heating system. The heat pump may operate in the solar-source mode whenever the storage tank temperature is between $40^{\circ} \mathrm{C}$ (above which direct heating is possible) and $0^{\circ} \mathrm{C}$ (at which the water would freeze). Electrical resistance heating is provided when the storage tank approaches its freezing point. This control strategy is shown in Figure 5. In the cooling mode, the heat pump rejects heat with an outdoor-air heat exchanger.

Preheating of the hot water supply is accomplished by heat exchange between the main storage tank and the preheat storage tank whenever a $5^{\circ} \mathrm{C}$ difference in tank temperatures exists.

A potential advantage of the series heat-pump configuration over a parallel configuration is that the tank temperature is of ten warmer than the outdoor air, thereby resulting in an increased heating-mode coefficient-of-performance. Furthermore, the lower temperature of the thermal storage tank, relative to the parallel heat-pump configuration, yields improved thermal and electrical PV/T collector efficiencies. In actual operation, a series heat-pump benefits 

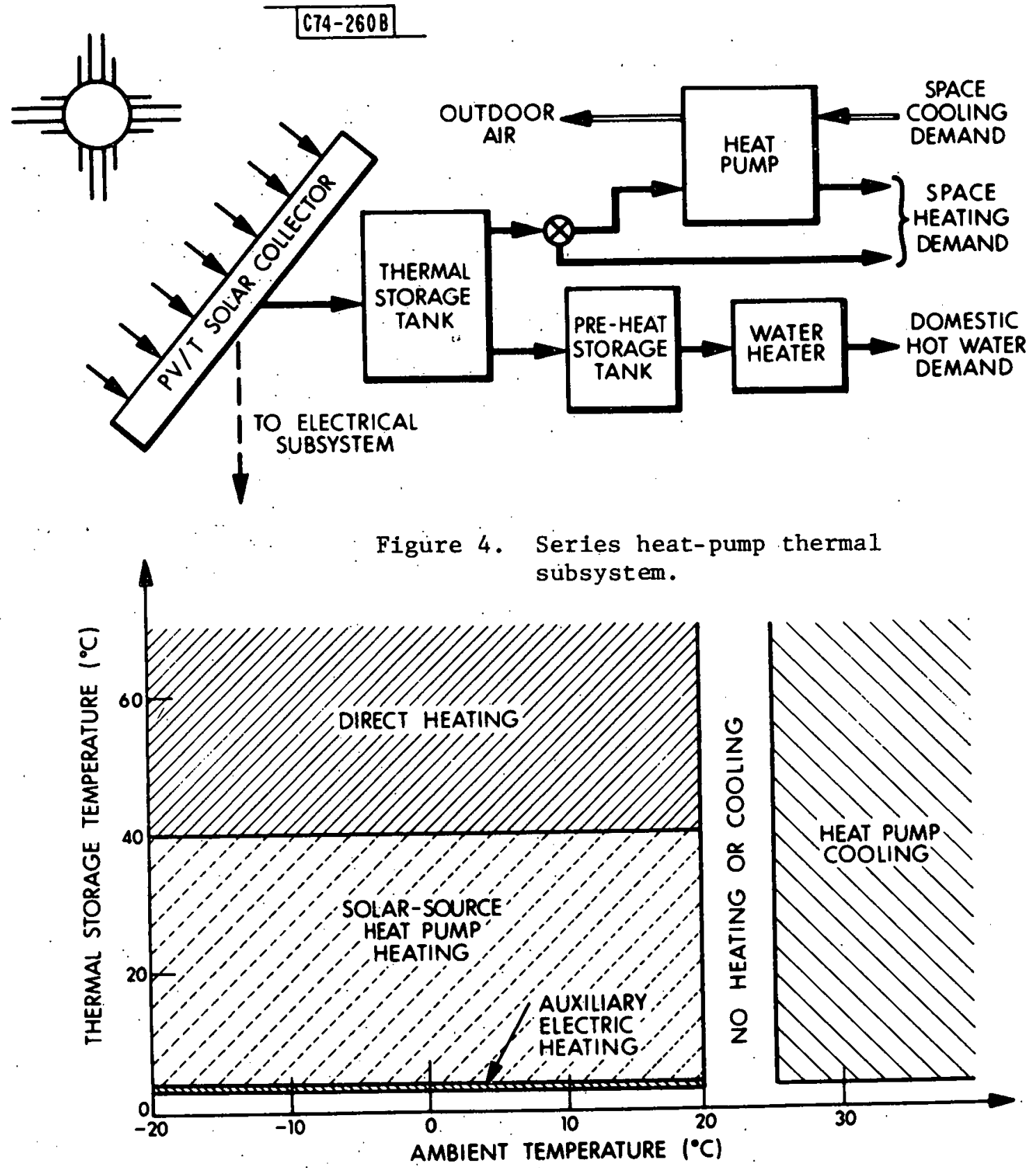

Figure 5. Series heat-pump thermal subsystem contro1 strategy.

additionally from improved evaporator heat transfer and elimination of the defrost cycle problems. 


\subsubsection{Parallel, or Ambient-Air-Source, Heat-Pump Thermal Subsystem}

A parallel heat pump, shown in Figure 6, operates in the heating mode with thermal energy supplied to its evaporator by outdoor ambient air. As before, collected thermal energy is stored in a water tank and the most efficient mode of space heating is direct heating from this tank. The heat pump supplies auxillary thermal energy when the tank temperature drops below $40^{\circ} \mathrm{C}$. Electrical resistance heating is provided when neither the thermal storage nor the heat pump are capable of satisfing the heating demand. The control strategy for this system is shown in Figure 7.

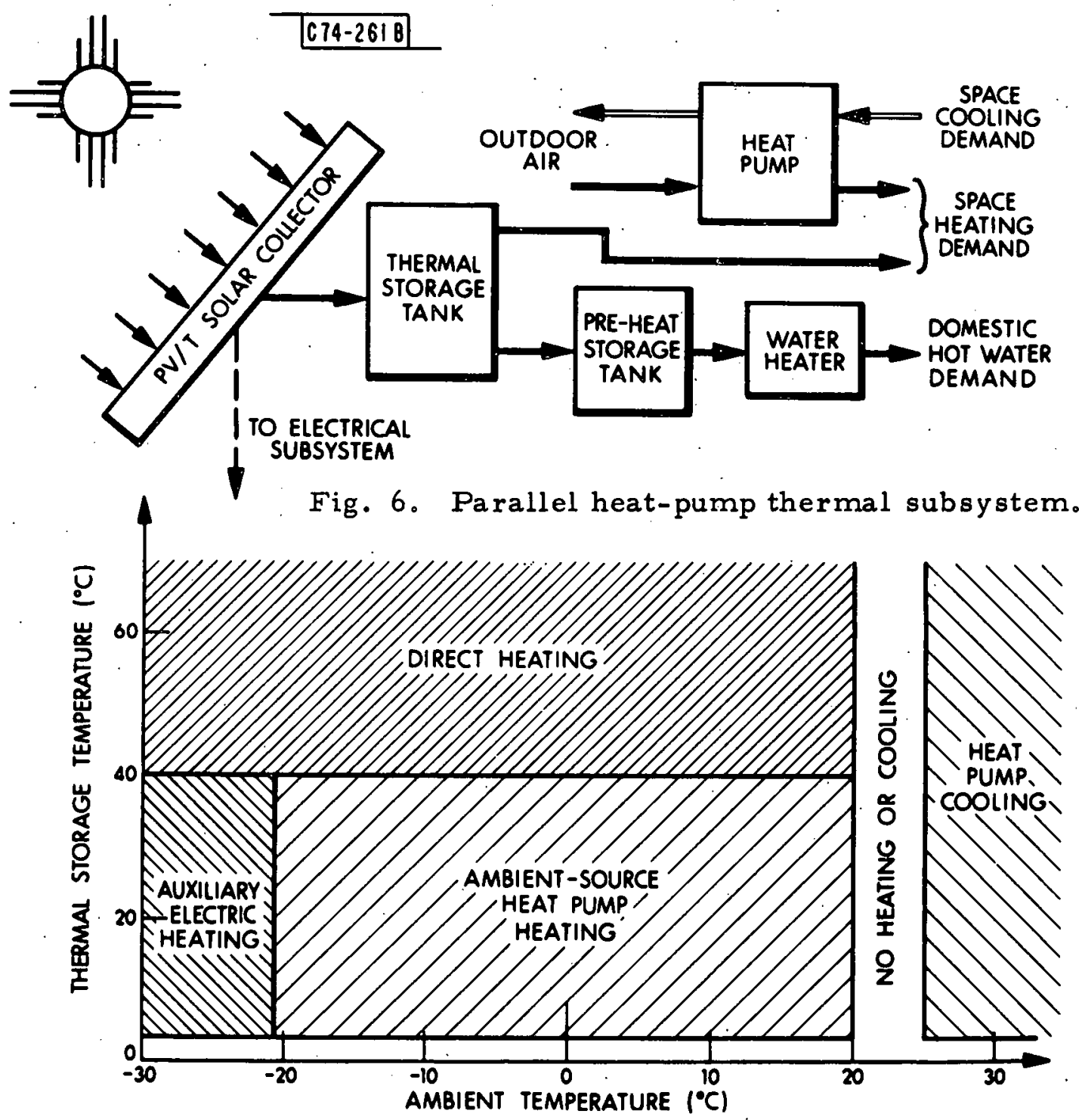

Fig. 7. Parallel heat-pump thermal subsystem control strategy. 
Space cooling is accomplished by the heat pump which rejects heat to the outdoor air. Domestic hot water preheating is accomplished by heat exchange between the main storage tank and the preheat storage tank whenever a $5^{\circ} \mathrm{C}$ difference in tank temperatures exists. The hotter the main storage tank, the greater the fraction of the domestic hot water demand provided by solar energy.

\subsubsection{Utility-Interactive Inverter Electrical Subsystem}

The simplest residential electrical subsystem consists of a utilityinteractive $\mathrm{DC}-$ to-AC power inverter with the capability to track the maximum power point of the photovoltatc array. This inverter allows photovoltalc array power in excess of the instantaneous demand to be directed to the utility. When auxiliary energy is required to meet the loads, it is provided by the utility through the interactive inverter. This electrical subsystem, depicted in Figure 8, assumes no on-site storage of electric energy.

\subsubsection{Electrical Subsystem with Storage}

A second electrical. subsystem considered uses on-site electrical storage. Excess electric energy generated by the solar array is stored in batteries or is dissipated in an outdoor resistive load to prevent overcharging of the batteries. Auxiliary energy is provided to the DC loads by an AC-to-DC rectifier. This system is depicted in Figure 9.

\subsection{Component Mode1s}

TRNSYS system performance simulations used a time step of 0.25 hours and covered the entire year ( 8760 hours). Among the subroutines added to the TRNSYS Iibrary were: a combined photovoltalc/thermal collector, a lead-acid battery, a power-dump battery-charge controller, and an energy time-of-use calculator to sum auxiliary energy use by electric utility time-of-use pricing periods.

The total annual auxiliary energy used during the utility peak, shoulder and of $\dot{f}$-peak hours was calculated in each simulation. Other quantities calculated included average coilector efficiency, average tank temperature, and heat-pump energy flows. 
<smiles>C1=CC2C=CC(=C1)C2</smiles>

\section{A.C. ELECTRICAL LOADS}

- heAT PUMP COMPRESSOR

- auxiliary space heating

- AuXILIARY dOMESTIC WATER HEATING

- PUMPS, FANS

Figure 8. Utility-interactive inverter electrical subsystem block diagram.

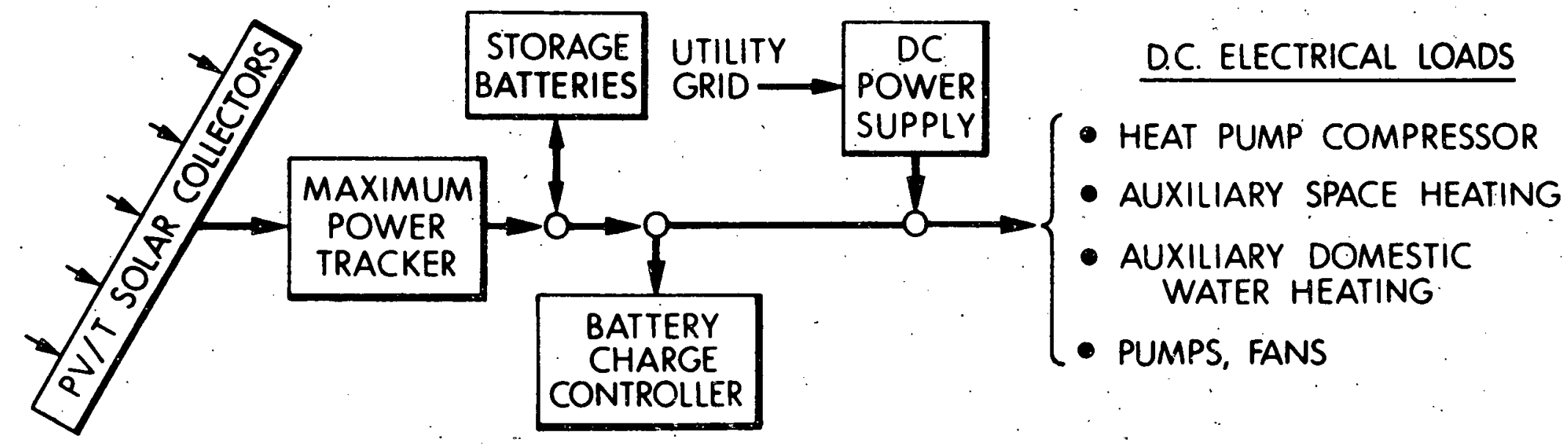

Figure 9. DC electrical subsystem with storage block diagram. 


\subsubsection{Heat Pumps}

Two heat pump models were used in the simulations. The parallel heatpump mathematical model was derived from an existing high-efficiency twospeed device. The heating coefficient-of-performance of this heat pump varies from 1.2 to 3.6 over the designed evaporator-source-temperature range of $-25^{\circ} \mathrm{C}$ to $20^{\circ} \mathrm{C}$. A plot of the performance of this unit is shown in Figure 10.

The model used for the series heat pump reflects the anticipated performance (Figure 10) of a device being developed. The heating-mode coefficient-ofperformance varies from 3.2 to 8.1 over the evaporator-source temperature range of $2^{\circ}$ to $40^{\circ} \mathrm{C}$. Existing parallel heat pumps are poorly suited to the elevated evaporating temperatures consistent with series operation (3). Operation of a parallel heat pump at evaporator temperatures in the range of $20-40^{\circ} \mathrm{C}$ generally results in high refrigerant vapor densities and mass flow rates which cannot be accommodated by the heat-pump compressor, heat exchangers ur expansion valve. Forced off-design operation in this temperature range results in coefficients-of-performance that are significantly lower than potentially attainable. Consequently, the U. S. Department of Energy has funded the development of heat pumps optimized for the higher-than-ambient

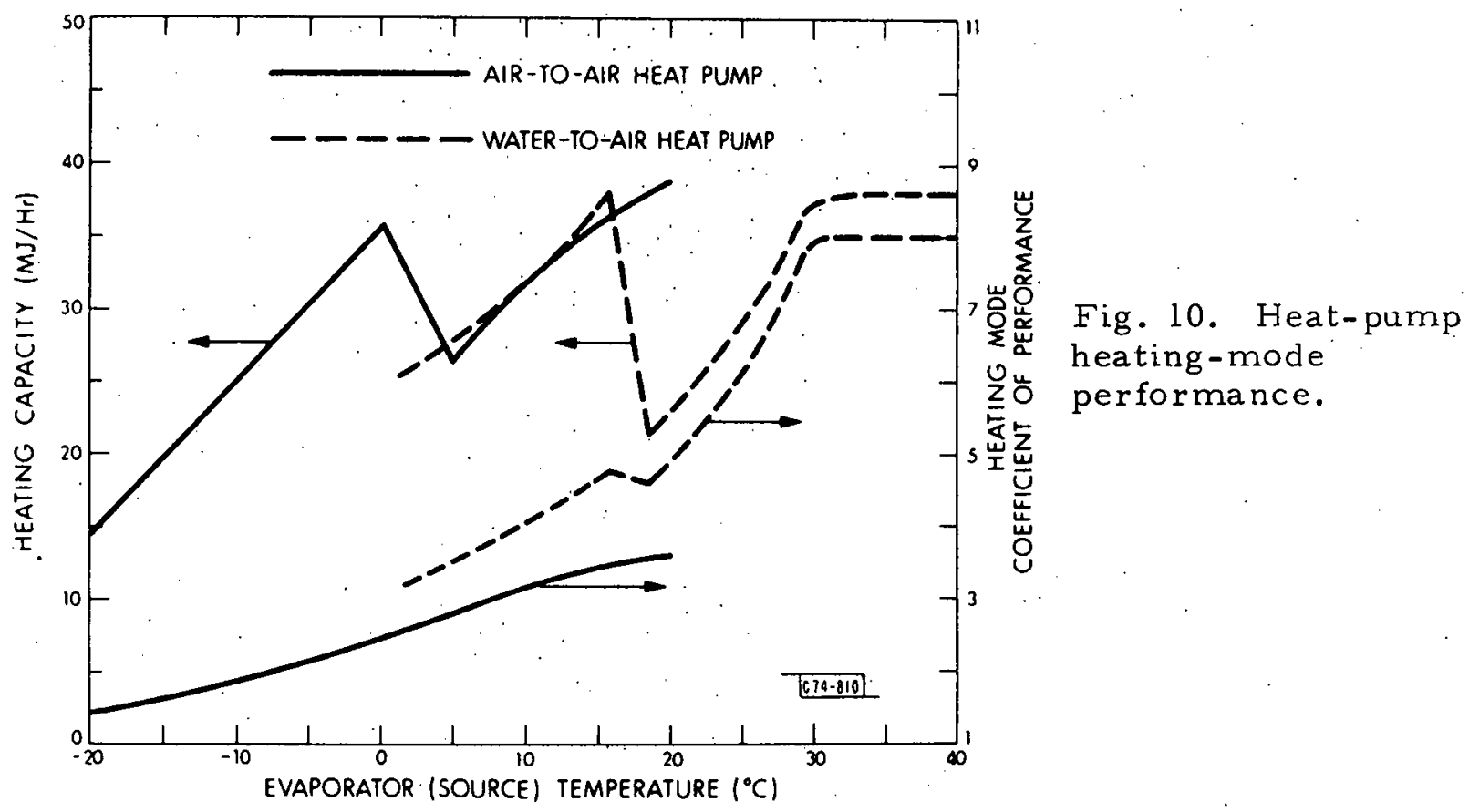


evaporating temperatures inherent in the series system.

The cooling-mode performance of each heat pump is shown in Figure 11.

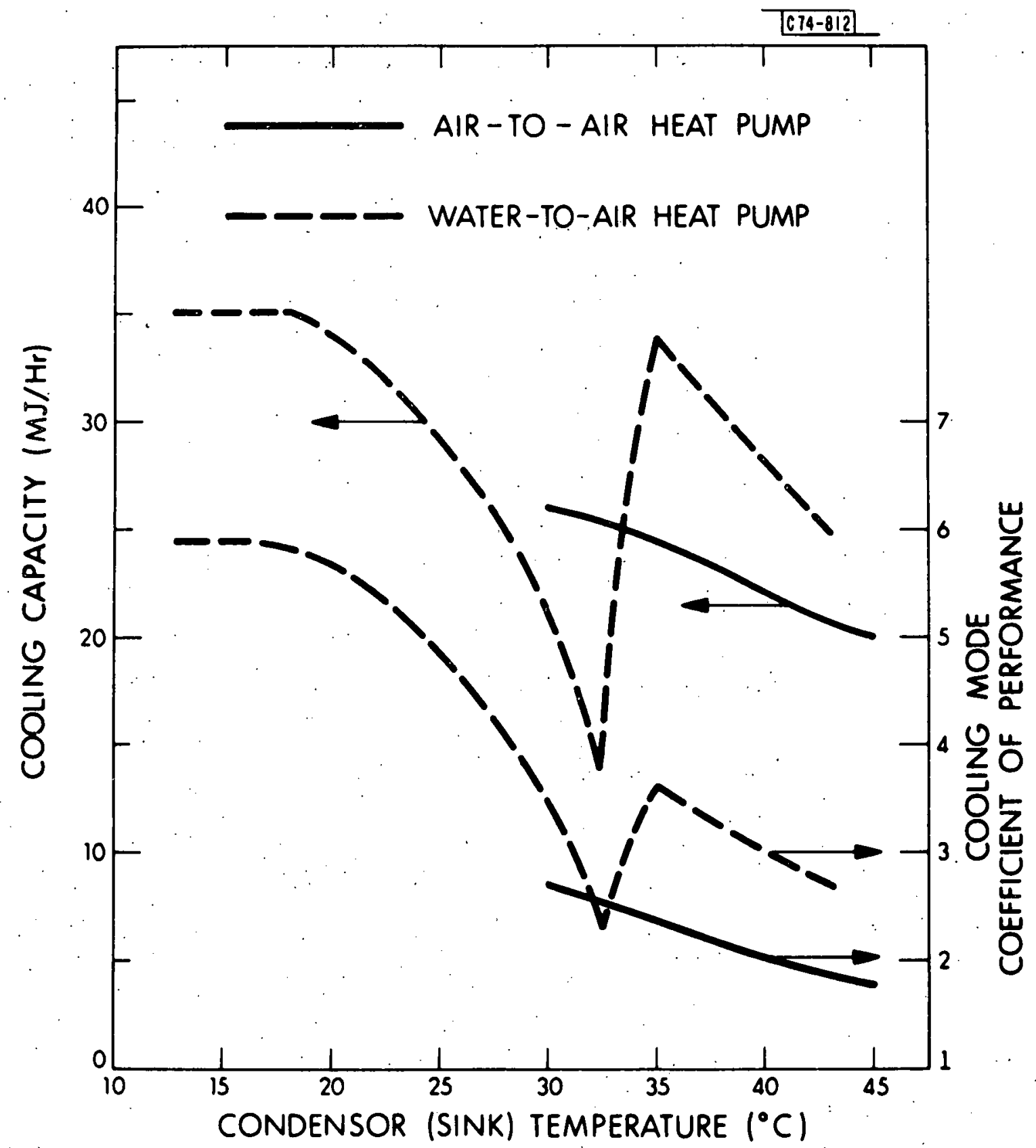

Fig. 11. Heat-pump cooling-mode performance. 


\subsubsection{Photovoltaic/Thermal Collector}

A modified Hottel, Whillier, Bliss collector model was used to simulate the dynamic thermal and electrical performance of a flat-plate combined photovoltaic/ thermal (PV/T) collector (4). The PV/T collector model assumed characteristics shown in Table 4.

TABLE 4

COMBINED PHOTOVOLTAIC/THERMAL COLLECTOR PERFORMANCE CHARACTERISTICS

$$
\begin{aligned}
& \text { Single glazed, transmissivity } \dot{\tau}=0.88 \\
& \text { Plate absorptivity, } \alpha=: 0.75 \\
& \text { Plate emissivity, } \varepsilon=0.75 \\
& \text { Bottom and edge heat loss } \\
& \text { coefficient, } U_{\text {be }}=1.06 \mathrm{~kJ} / \mathrm{hr}-{ }^{\circ} \mathrm{C}-\mathrm{m}^{2} \\
& \text { Collector efficiency factor, } F^{\prime}=0.9 \\
& \text { Encapsulted photovoltaic cell } \\
& \text { effictency at } 25^{\circ} \mathrm{C}, \eta_{r}=0.12 \\
& \text { Temperature coefficient of photovgltaic } \\
& \text { cell effictency, } B_{r}=5 \times 10^{-3} \\
& \text { Geometrical soḷar cell packing density, } \\
& P_{f}=0.9
\end{aligned}
$$

The approximate thermal and electrical performance of this collector is shown in Figure 12. The coolant 11quid was assumed to be an antifreeze solution $\left(C_{p}=3.35 \mathrm{KJ} \mathrm{Kg}^{-1} \mathrm{c}^{-1}\right.$, for water $\left.\mathrm{C}_{\mathrm{p}}=4.186 \mathrm{KJ} \mathrm{Kg}^{-1}{ }^{\circ} \mathrm{C}^{-1}\right)$. The 11quid mass flow rate through the collectors was varied from 50 to $100 \mathrm{~kg} / \mathrm{hr}-\mathrm{m}^{2}$. Collector tilt angle was assumed to be $50^{\circ}$ for the New York residence and $40^{\circ}$ for the Fort Worth residence.

A simple solar thermal collector was also modelled. Its characteristics were assumed to be similar to those of the $\mathrm{PV} / \mathrm{T}$ collector with the exceptions of higher absorptivity, 0.9, and lower emissivity, 0.6. A photovoltaic collector was modelled assuming the same cell characteristics and packing factor as 
in the $\mathrm{PV} / \mathrm{T}$ collector, but without the cover-glazing-related optical losses. and thermal gains.
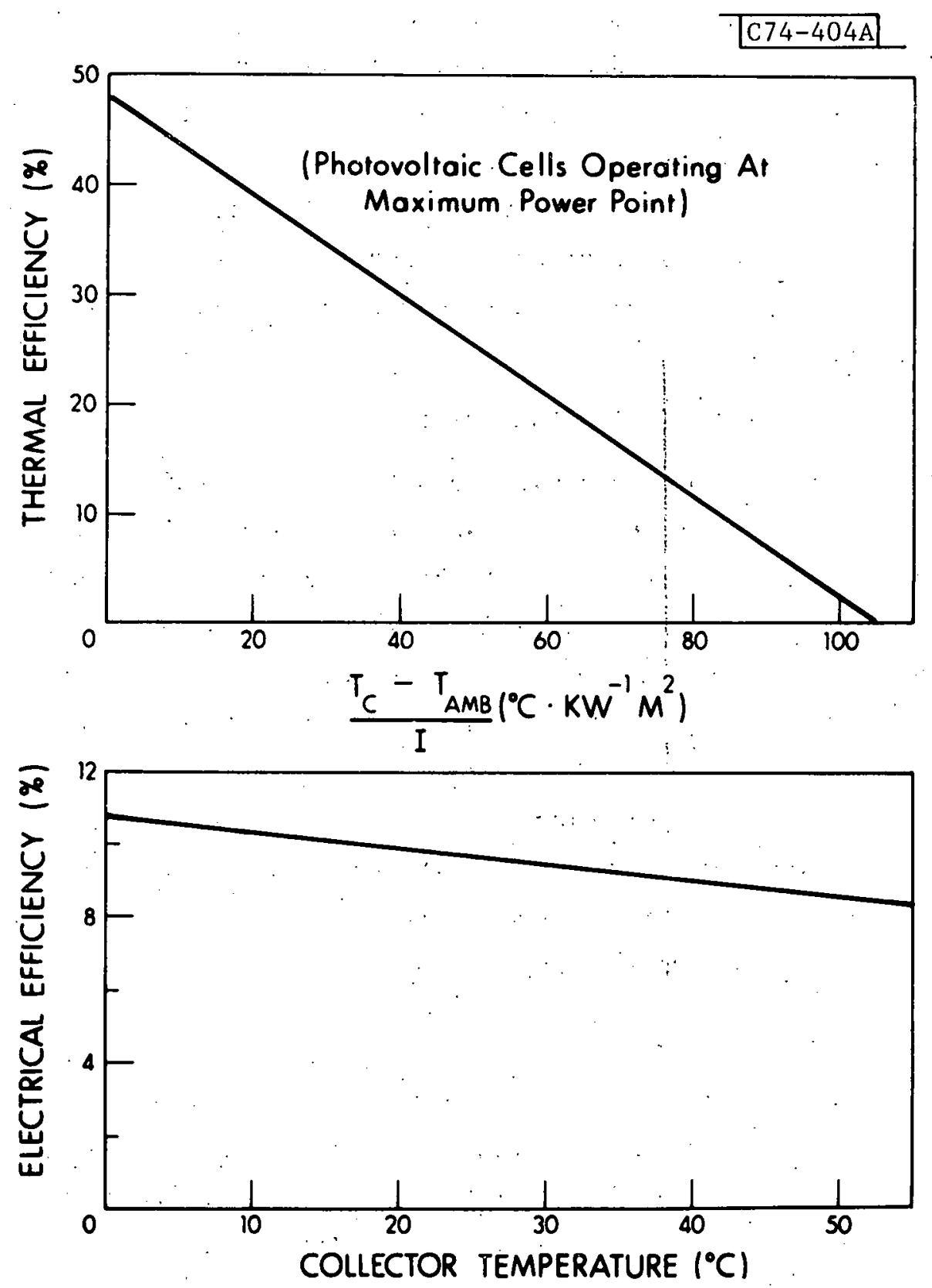

Figure 12. Combined photovoltaic/ thermal collector performance. 


\subsubsection{Electrical Subsystem Components}

A simple battery model which assumes a constant $84 \%$ throughput energy efficiency was used. The storage capacity used in a system was varied from 0.2 to 0.5 kilowatt-hours per square meter of PV/T (or PV) collectors. To prevent battery overcharging, a resistive power dump and appropriate controls were used. Auxiliary electric power in the DC subsystem was provided through a battery charger with constant efficiency of 0.95 .

The utility-interactive inverter was assumed to have a constant efficiency of 0.90 , typical of current technology hardware. The inverter's assumed photovoltaic-array maximum-power-point tracking capability is incorporated in some currently available units.

\subsubsection{Thermal Subsystem Components}

The collector loop containing an antifreeze solution was thermally linked to the main storage tank by a constant-effectiveness (0.75) heat exchanger. The main storage tank was assumed to be 1.5 meters high regardless of its volume, and to have a loss coeffictent of $0.42 \cdot \mathrm{W} \cdot \mathrm{m}^{-2} \cdot{ }^{\circ} \mathrm{C}^{-1}$.

The domestic hot water subsystem consisted of a 227-11ter preheat tank which was thermally linked to the main tank by a constant-effectivness $(0.7)$ heat exchanger.

Parasitic power requirements were assumed for the pumps and fans in the thermal subsystem, amounting to 74 watts each in the collector and storage tank loops, 37 watts in the domestic water preheat loop, and 370 watts each for the air-space blower and the outdoor fan/coll unit.

\subsection{Economic Analysis}

A life-cycle cost analysis was made for each system simulated. This analysis utilized the total annual auxiliary energy prediction calculated by TRNSYS and the economic assumptions listed in Table 5. The levelized annual system cost includes the costs of capital, system operation and maintenance, and auxiliary energy. The basic component costs assumed in this analysis are shown in Table 6 . 
TABLE $\cdot 5$

SYSTEM ECONOMIC ASSUMPTIONS

$\begin{array}{ll}\text { System lifetime, } t & 20 \text { years } \\ \text { Mortgage rate, } i & 9 \% \\ \text { General inflation rate, } j & 6 \% \\ \text { Fuel inflation rate, } j_{e} & 10 \% \\ \text { Homeowners tax bracket, } T_{\text {inc }} & 35 \% \\ \text { System installation date } & 1986 \\ \text { Federal tax credit } & 30 \% \text { (up to } \$ 2000) \\ & 20 \% \text { (next } \$ 8000)\end{array}$

TABLE 6

COMPONENT PRICE ASȘUMPTIONS

(1986 price, 1975\$s)

\begin{tabular}{|lr|}
\hline Combined PV/T collector $\left(\$ / \mathrm{m}^{2}\right)$ & 125 \\
Thermal collector $\left(\$ / \mathrm{m}^{2}\right)$ & 75 \\
Photovoltaic module $\left(\$ / \mathrm{m}^{2}\right)$ & 75 \\
Alr-to-air heat pump $(\$)$ & 1500 \\
Water-to-air heat pump $(\$)$ & 1850 \\
Thermal storage tank $(\$ / \mathrm{kg})$ & 0.20 \\
DC-AC inverter $(\$ / \mathrm{kVA})$ & 150 \\
AC-DC rectifier $(\$ / \mathrm{system})$ & 900 \\
Storage batteries $(\$ / \mathrm{kWh})$ & 65 \\
Battery related cost $(\$ /$ system) & 1000 \\
DC system related cost $(\$ / \mathrm{system})$ & 600 \\
Thermal system costs $(\$ /$ system) & $\therefore$ \\
\hline
\end{tabular}


A time-of-use utility rate (TOUR) structure was assumed in calculating the cost of auxiliary energy. Data for two experimental TOUR schedules, Figure 13, show the seasonal and daily variation in the per-kWh price of energy.

C74-817]

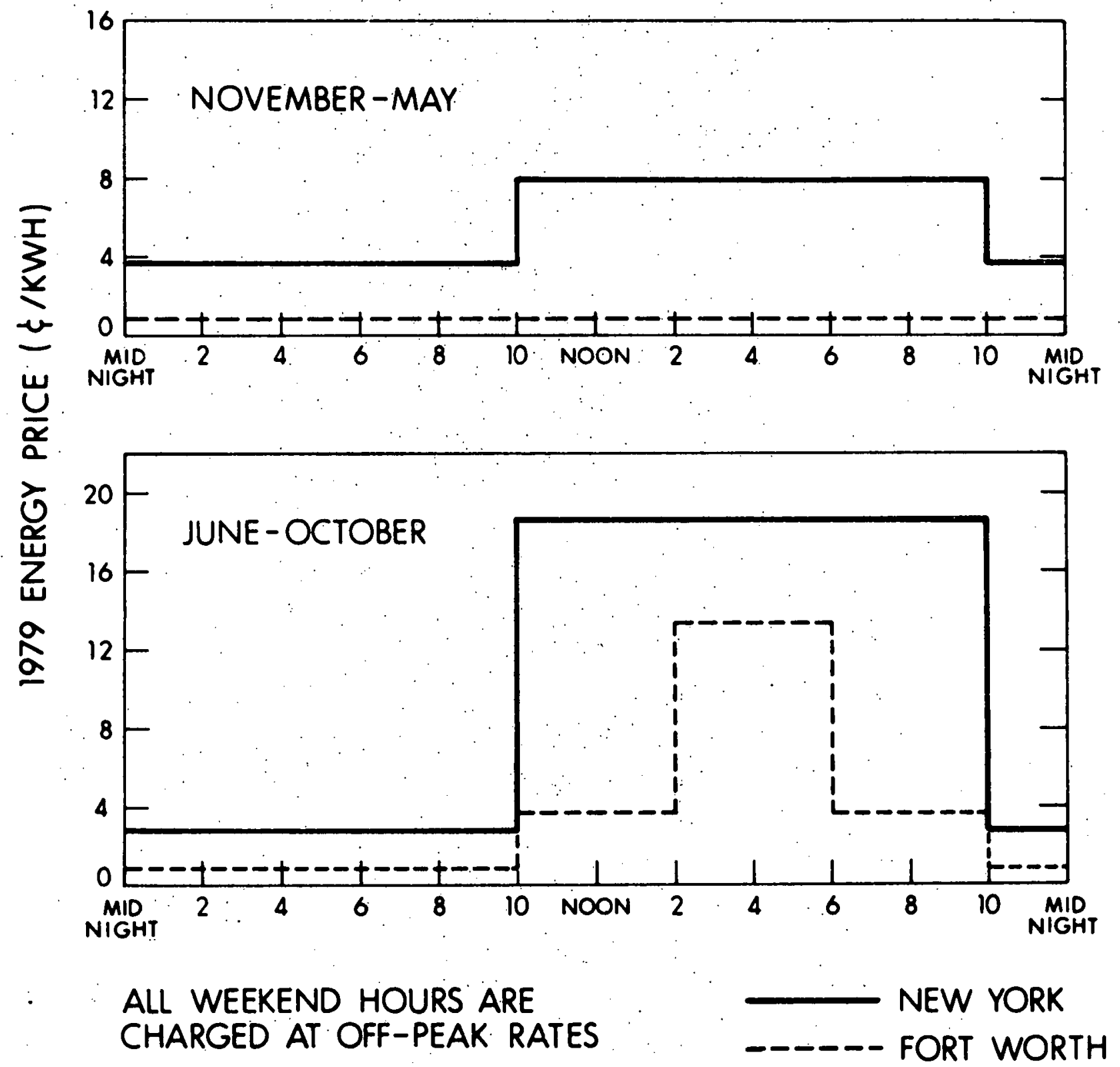

Fig. 13. Time-of-use utility rate schedule: 
The monthly billing for auxillary energy consists of the fixed amount plus the per-kWh amount. Over the system lifetime, this fixed amount was increased at the general inflation rate and the per-kWh charge was increased at the average of the fuel and general inflation rates. Half the per-kWh cost to the consumer for electrical energy under a time-of-use rate schedule is assumed to be for fuel and half for transmission and distribution. This yields a net increase in the per-kWh energy cost of $8 \%$ per year.

The levelized annual system cost reflects the annual cost of owning, operating and maintaining the photovoltaic system over its lifetime. The first step in calculating this quantity is to determine the current dollar* after tax cash flow for each year of system operation. This quantity is equal to the sum of net capital cost, operation and maintenance costs, auxiliary energy cost and net component replacement cost.

In the following definitions, Cs represents costs in $1975 \$$ and Es represents energy measured in kllowatt-hours:

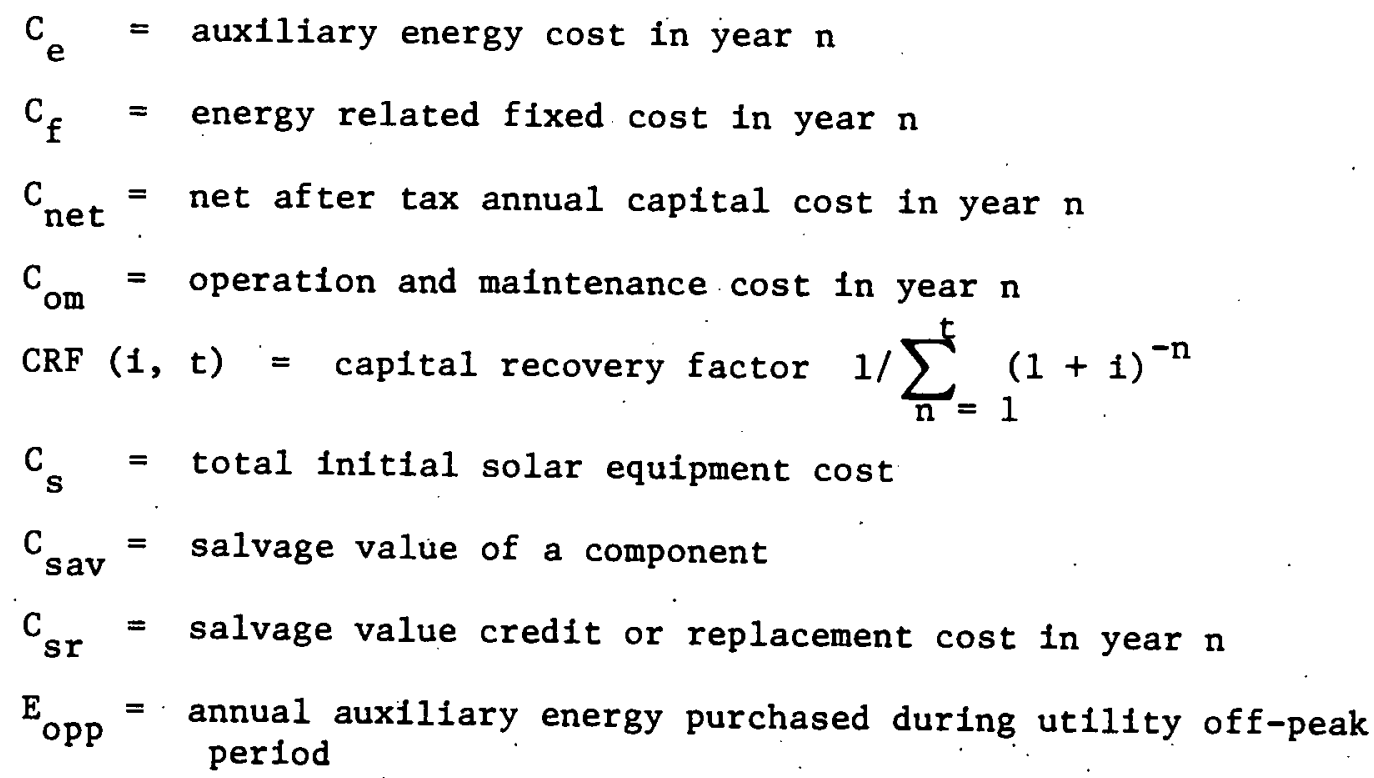

*Current Dollars: The number of dollars associated with a specific real value at a given time, subject to change at the general inflation rate. Food costs are always in current dollars.

Constant Dollars: A number of dollars which does not change regardless of the effect of inflation. Mortgage payments are in constant dollars. 

$E_{\text {op }}=\begin{gathered}\text { annual photovoltalc electric energy sold back during utility } \\ \text { off-peak period }\end{gathered}$

$\mathrm{E}_{\mathrm{pkp}}=$ annual auxiliary energy purchased during utility peak period

$\mathrm{E}_{\mathrm{pks}}=$ annual photovoltafic electric energy solar back during utility peak period

$E_{\text {shp }}=$ annual auxiliary energy purchased during utility shoulder period

$E_{\text {shs }}=$ annual photovoltafc electric energy sold back during utility shoulder period

$\mathrm{n} \quad=$ year of system operation

$\mathrm{P}_{\mathrm{n}}=$ remaining principle in year $\mathrm{n}$

$\mathrm{T}_{\text {ann }}=$ net after tax annual current dollar cash flow

$\eta_{S}=$ energy sellback-to-buy ratio

The annual cash flow is, then

$\mathrm{T}_{\text {ann }}=\mathrm{C}_{\text {net }}+\mathrm{C}_{\text {om }}+\mathrm{C}_{\mathrm{e}}+\mathrm{C}_{\text {sr }}$,

where

$C_{\text {net }}=C_{s} \times \operatorname{CRF}(1, t)-T_{\text {inc }} x P_{n}$,

and

$$
\begin{gathered}
c_{\text {om }}=02 \times c_{s}(1+j)^{n}, \\
c_{e}=c_{p k}\left(E_{p k p}-\eta_{s} E_{p k s}\right)+c_{s h}\left(E_{s h p}-{ }_{s}^{E}{ }_{s h s}\right)+C_{o p} \\
\left(E_{\text {ops }}-\eta_{s} E_{o p s}\right)+c_{p}
\end{gathered}
$$


and

$$
\mathrm{C}_{\text {sr }}=-\mathrm{C}_{\text {salv }}+\mathrm{C}_{\text {rep }} \text {. }
$$

The cost of energy is based upon the time-of-use rate schedule and an assumed sellback-to-buy rate ratio of $0.5 . \therefore$ The annual fixed cost, $C_{f}$, associated with purchase of energy is the sum of the monthly charges, including city and state taxes where applicable.

A salvage value of $15 \%$ of the original cost is assumed for batteries after ten years of service and for heat pumps after 20 years of service. A $10 \%$ salvage value is assumed for solar collectors after 20 years. These credits and the battery replacement cost after 10 years are included in $\mathrm{C}_{\mathrm{sr}}$ for the appropriate year.

Operation and maintenance charges are assumed to be $2 \%$ of the total inftial cost annually. This cost escalates at the general inflation rate.

The 1986 dollar present value, $\mathrm{PV}_{86}$, of all yearly expenditures over the system iffetime is:

$$
\mathrm{PV}_{86}=\sum_{\mathrm{n}=1}^{20} \mathrm{~T}_{\mathrm{ann}} /\left[1+1\left(1-\mathrm{T}_{\text {inc }}\right)\right]^{\mathrm{n}} .
$$

The levelized annual cost, LAC, is the present value multiplied by the capital recovery factor

$$
\mathrm{LAC}=\mathrm{PV}_{86} \times \mathrm{CRF}\left(\dot{t}^{\prime}, t\right)
$$

where

$$
\begin{aligned}
i^{\prime} & =\text { effective after tax discount rate } \\
& =\left[1\left(1-T_{1 \text { nc }}\right)-j\right] /(1+j) .
\end{aligned}
$$




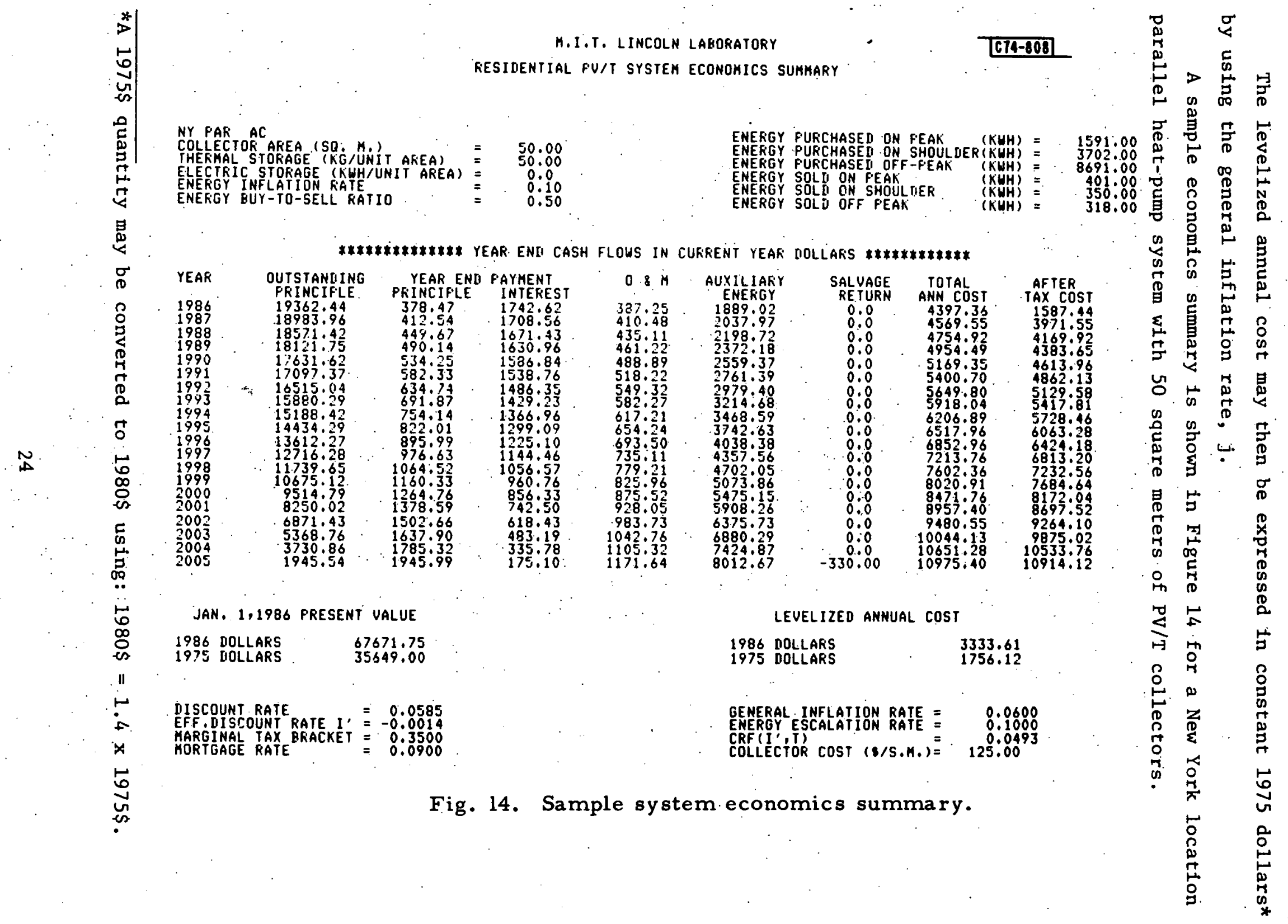


This Section presents the results of performance and economic analysis for both the New York and Fort Worth residences.

\subsection{New York Residence System Performance Results}

Figure 15 shows the percentage of the total electrical and thermal demand provided by solar energy, as a function of collector area for three systems in the New York residence.

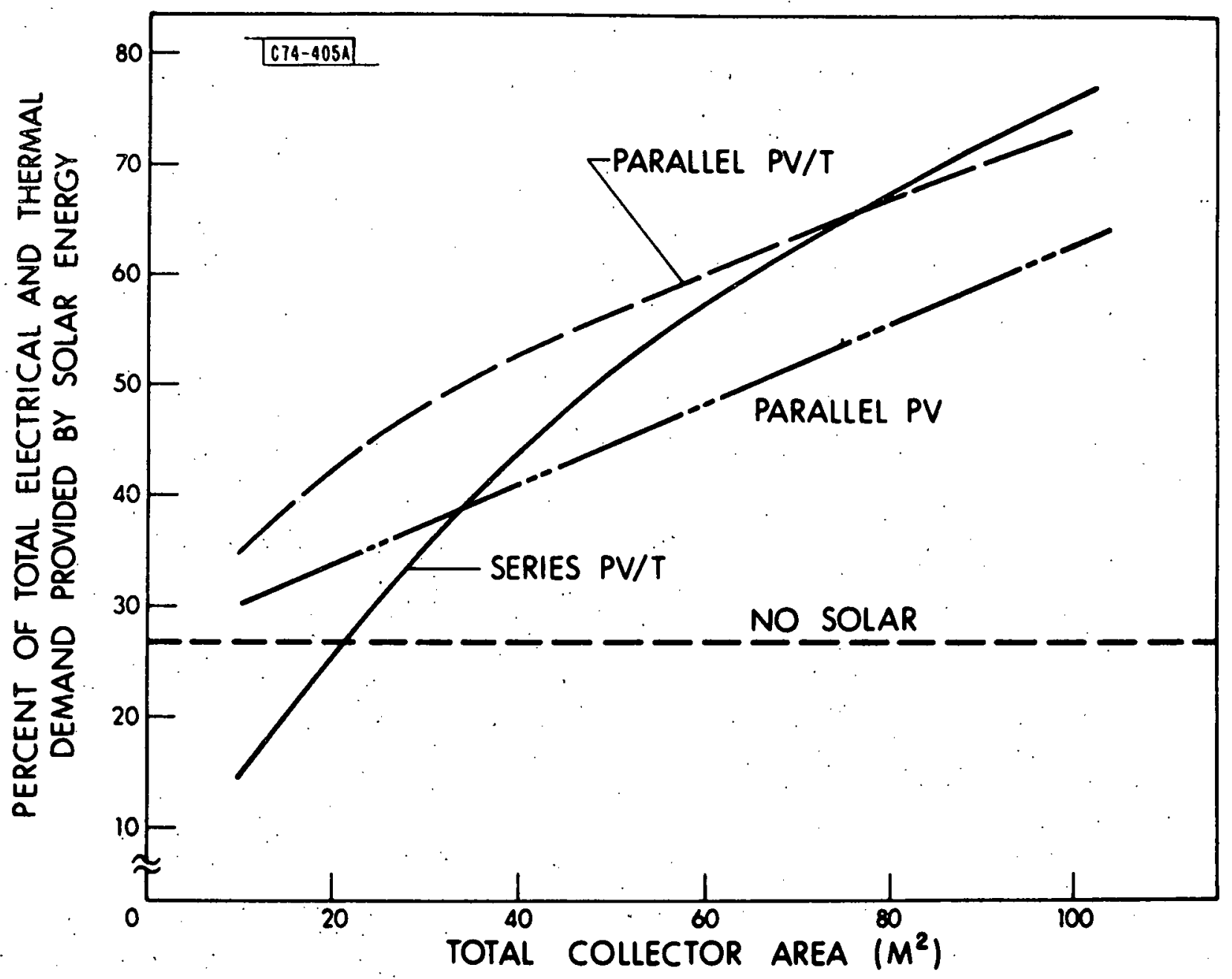

Fig. 15. New York residence (with utility-interactive electrical subsystem) system performance results. 
Each system shown utilized the AC utility-interactive subsystem. The annual percent solar is calculated as:

$$
f_{s}=\left[1-\frac{E_{p}-E_{s}}{Q_{s h}+Q_{c}+Q_{d h w}+E_{d i v}}\right] \times 100
$$

where

$$
\begin{aligned}
& E_{\mathrm{div}}=\text { diversified electrical load } \\
& \mathrm{E}_{\mathrm{P}}=\text { electrical energy purchased } \\
& \mathrm{E}_{\mathrm{S}}=\text { electrical energy sold to the utility } \\
& \mathrm{f}_{\mathrm{S}=} \text { percent of the total electrical and thermal demand provided by } \\
& \quad \text { solar energy. } \\
& \mathrm{Q}_{\mathrm{C}}=\text { space cooling thermal load } \\
& \mathrm{Q}_{\mathrm{dhw}}=\text { domestic hot water thermal load } \\
& \mathrm{Q}_{\mathrm{sh}}=\text { space heating thermal load }
\end{aligned}
$$

The conventional system, utilizing a parallel heat pump without solar collectors, provides approximately $27 \%$ of the load by solar energy because the heat pump extracts energy from the outdoor air (indoor air in the cooling mode) at a coefficient-of-performance greater than 1. As the collector area approaches zero, both parallel heat-pump systems approach the conventional system performance, as expected. The series heat pump without collectors, however, relies completely upon electrical resistance for space heating and, therefore, solar sources supply virtually none of the residential loads in this case (the small cooling load is still met by the heat pump at COP greater than 1).

Even at modest collector areas there is of ten insufficient stored thermal energy available to the heat-pump evaporator to allow full-time serles heatpump heating. When this "starvation" condition-occurs, the space-heating load is met by electrical resistance heating at a COP of 1 . Consequently the potentially high COP advantages of the series heat pump are realized only with 
collector areas greater than 75 square meters. At these large PV/T collector areas, the total auxiliary energy required by the series heat-pump system is" slightly less than that required by the parallel heat-pump system. Both the series and parallel heat-pump configurations utilizing $\mathrm{PV} / \mathrm{T}$ collectors provide a greater percentage of the total load than the parallel configuration using simple photovultalc collectors. This is due to the inability of the PV system to accomplish either direct space heating or domestic hot water preheating.

Figure 16 shows the percent solar as a function of collector area for a parallel heat pump configuration using the DC electrical subsystem. This system using PV/T collectors provides approximately 10 percent less of the total demand than the comparable system using the AC utility-interactive subsystem. Greater amounts of auxiliary energy are required for the DC system because: the throughput efficiency of the storage batteries is .84, whereas the AC subsystem utilizes the utility grid as storage at an effective efficiency of 1.0 ; all auxiliary energy is provided through a battery charger with an efficiency of 0.95; at large collector areas, some PV energy is dissipated to prevent battery overcharging.

Fi.g. 16. New York residence (with DC electrical subsystem with storage) system performance results.

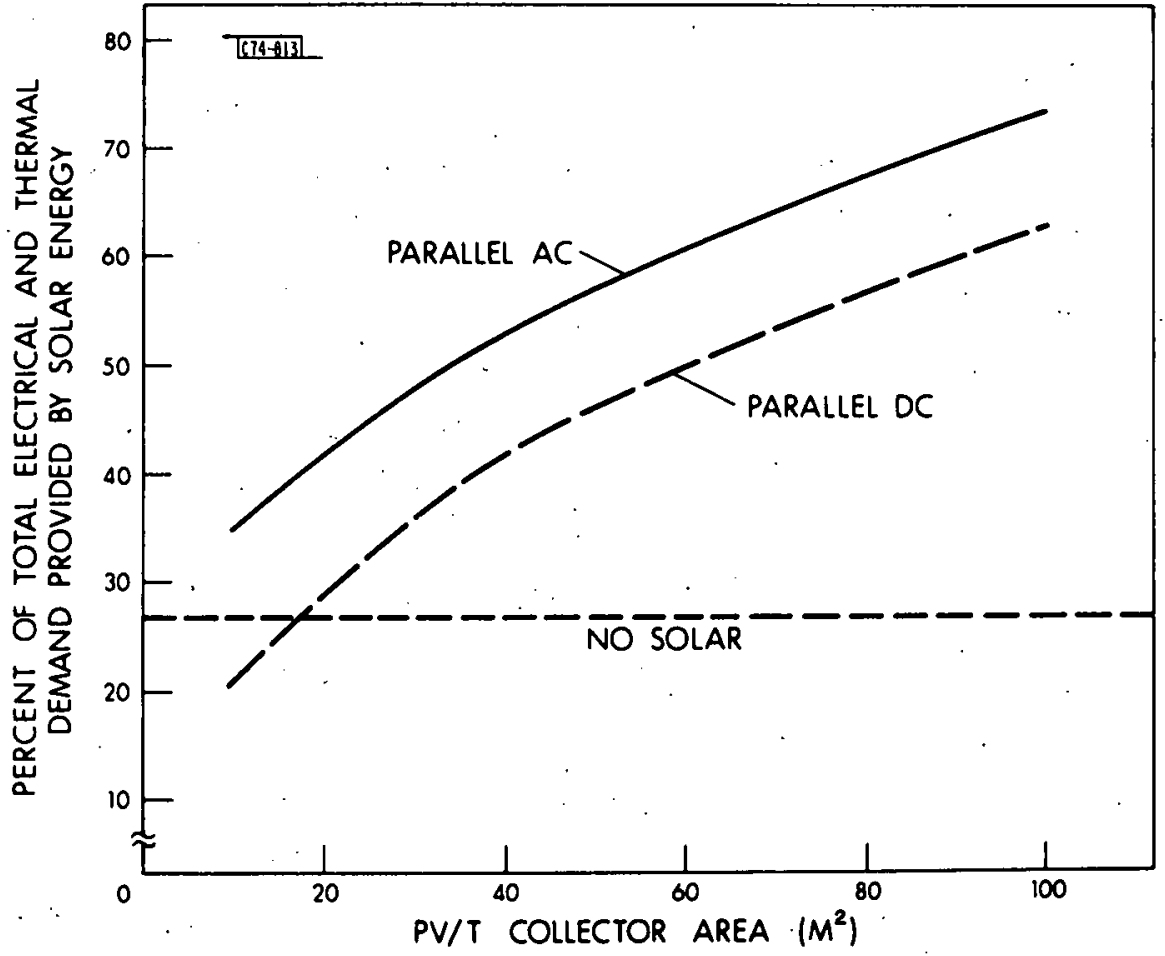


Table 7 lists the percent solar for the parallel heat-pump configuration with the AC utility-interactive subsystem utilizing a solar array consisting. of separate photovoltaic and thermal collectors in the New York residence.

TABLE 7

ENERGY PERFORMANCE OF A NEW. YORK RESIDENCE UTILIZING SEPARATE PHOTOVOLTAIC AND THERMAL COLLECTORS

\begin{tabular}{|c|c|c|c|c|}
\hline Total. & $\begin{array}{l}\text { Collector Ar } \\
\text { Photovoltaic }\end{array}$ & Thermal & & $\begin{array}{l}\text { Percent } \\
\text { Solar. } \\
\end{array}$ \\
\hline 50 & 25 & 25 & '. & 51.1 \\
\hline 75 & 25 & 50 & & 54.4 \\
\hline 75 & 50 & 25 & & 62.1 \\
\hline 100 & 25 & 75 & & $56: 6$ \\
\hline 100 & 50 & 50 & & 65.4 \\
\hline 100 & 75 & 25 & & 73.1 \\
\hline
\end{tabular}

For a fixed total collector area, the systems utilizing PV/T collectors supply a greater percentage of the residential demands than any of the combinations of separate photovoltaic and thermal collectors. For example, the parallel heat-pump configuration using $75 \mathrm{~m}^{2}$ of $\mathrm{PV} / \mathrm{T}$ collectors results in 65.4 percent solar which is greater than that for both separate collector. combinations in Table 7 using a total collector area of $75 \mathrm{~m}^{2},(54.4$ and 62.1$)$.

\subsection{New York Residence System Economic Forecasts}

The economic forecasts for three systems in the New York residence are. indicated in Figure 17, which shows the levelized annual system cost as a function of the total collector area. This figure reflects the component costs and economic assumptions listed previously. The most economical system for the New York residence is the parallel heat-pump configuration with 


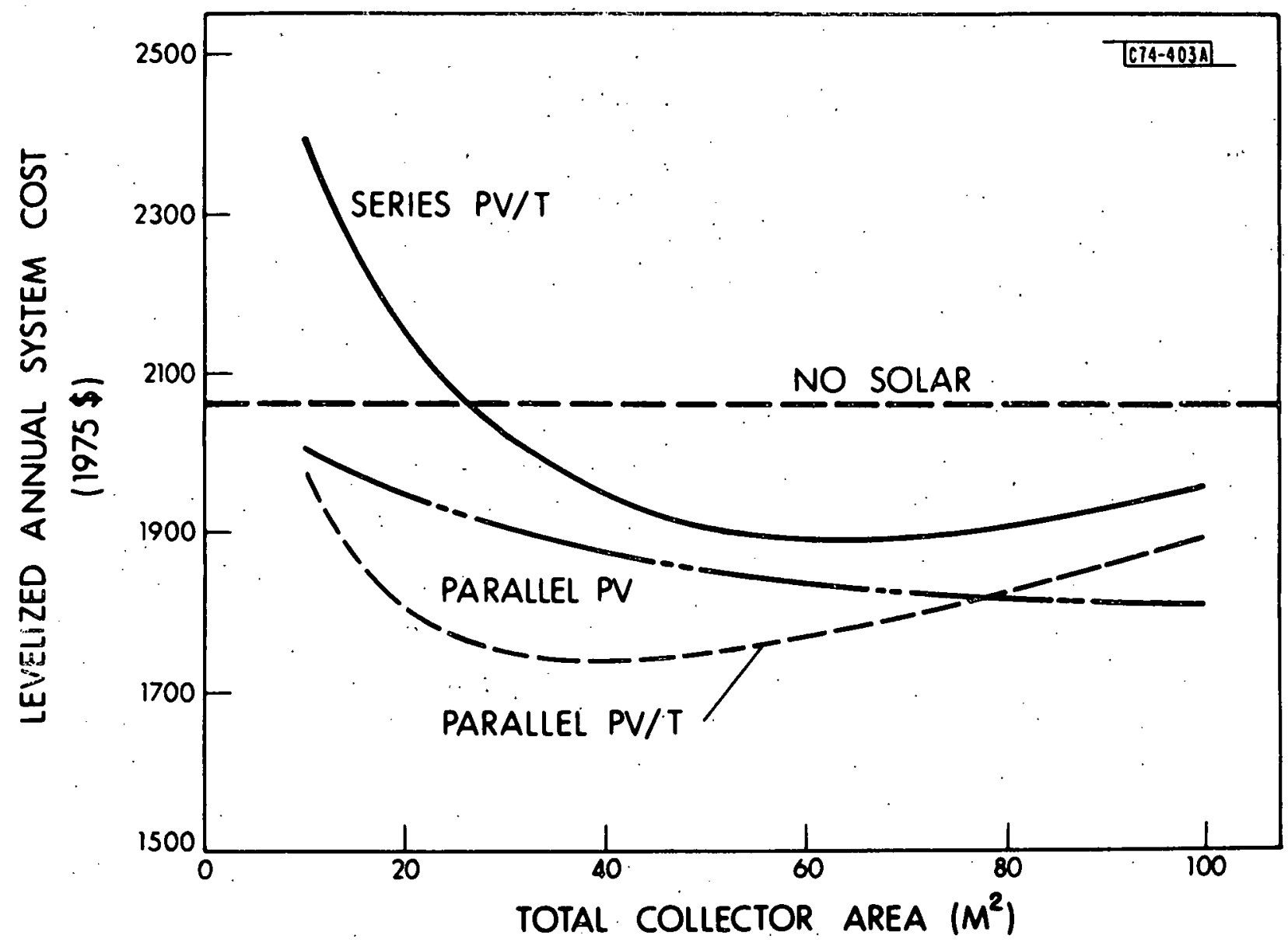

Fig. 17. New York residence (with utility-interactive electrical subsystem) system economic forecasts.

approximately 40 square meters of $\mathrm{PV} / \mathrm{T}$ collectors, at a levelized annual cost of $\$ 1740$. Despite the reduced auxiliary energy required by the series heatpump system at large collector areas, this system is consistently more expensive than the parallel heat-pump systems with equal collector areas since auxiliary energy savings are offset by the cost of the larger thermal energy storage found optimal for the series system.

Figure 18 shows the levelized annual cost for the parallel heat-pump configuration with the battery-storage electrical subsystem. The cost of this system using PV/T collectors is significantly greater than that of the corresponding utility-interactive parallel system due to the initial high cost of batteries and their protective housing. 


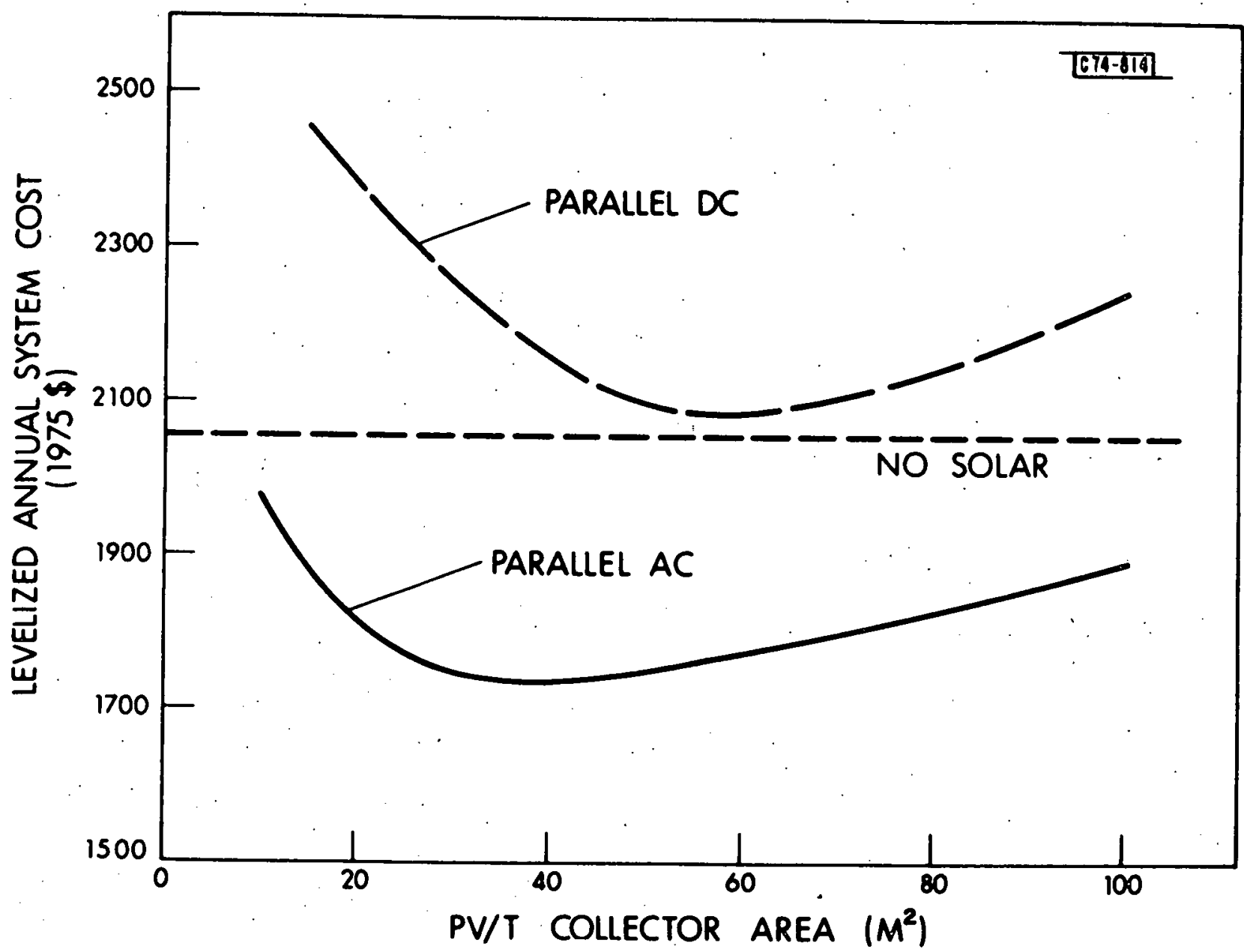

Fig. 18. New York residence (with DC electrical subsystem. with storage) system economic forecasts.

Table 8 lists the levelized annual cost for the parallel heat-pump configuration utilizing separate photovoltaic and thermal collectors.

Figure 19 shows the levelized annual cost of the PV/T parallel heat-pump system for three PV/T collector prices: $\$ 100, \$ 125$ and $\$ 150 / \mathrm{m}^{2}$. Also shown are the levelized annual system costs for a parallel system utilizing combinations of separate photovoltaic and thermal collectors $\left(\$ 75 / \mathrm{m}^{2}\right.$ for each collector type). For a total collector area of $50 \mathrm{~m}^{2}$ and a PV/T collector cost of $\$ 100 / \mathrm{m}^{2}$, separate collectors $\left(25-\mathrm{m}^{2} \mathrm{PV}\right.$ and $25-\mathrm{m}^{2}$ thermal) and $\mathrm{PV} / \mathrm{T}$ collectors result in virtually the same levelized annual system cost. A separate-collector parallel heat-pump system with more than $50 \mathrm{~m}^{2}$ of available 
TABLE 8

LEVELIZED ANNUAL COST OF A NEW YORK

RESIDENCE UTILIZING SEPARATE

PHOTOVOLTAIC AND THERMAL COLLECTORS

\begin{tabular}{|ccc|c|}
\hline Total & $\begin{array}{c}\text { Collector Area }\left(\mathrm{m}^{2}\right) \\
\text { Photovoltaic }\end{array}$ & Thermal & $\begin{array}{c}\text { Levelized } \\
\text { Annual System } \\
\text { Cost (1975\$) }\end{array}$ \\
\hline 50 & 25 & 25 & 1654. \\
75 & 25 & 50 & 1726. \\
75 & 50 & 25 & 1562. \\
100 & 25 & 75 & 1828. \\
100 & 50 & 50 & 1639. \\
100 & 75 & 25 & 1505. \\
\hline
\end{tabular}

Fig. 19. New York residence system economic forecasts for separate thermal and photovoltaic collector systems.

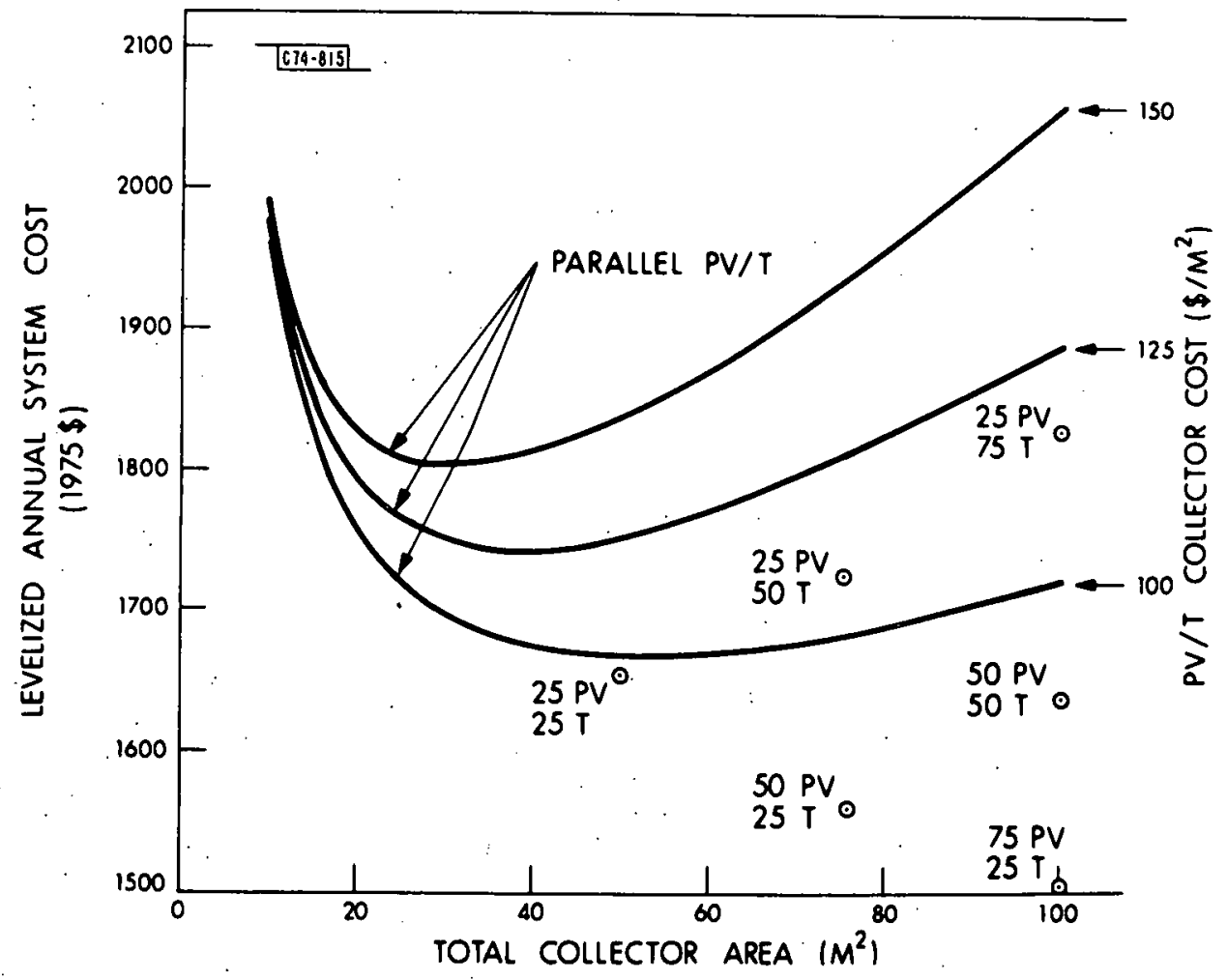


roof can result in a lower levelized annual cost than the least-cost $\mathrm{PV} / \mathrm{T}$ collector system; this, however, requires large roof area.

\subsection{Fort Worth System Performance Results}

Figure 20 shows the percent solar as a function of collector area for three systems in the Fort Worth residence. All systems shown used the utility-interactive AC subsystem. No DC systems were considered for the Fort Worth location due to the high cost for these systems found in the New York residence simulation. The trends in these curves are the same as those for the New York residence. In the Fort Worth location, however, which is characterized by a high cooling demand and moderate heating requirement, the benefits of the series system over the parallel systems are shown for $\mathrm{PV} / \mathrm{T}$ collector areas above approximately $55 \mathrm{~m}^{2}$. At zero collector area, both parallel systems approach the performance of the conventional non-solar system. The three systems shown all meet more than $50 \%$ of the total residential demands given collector areas larger than 40 square meters.

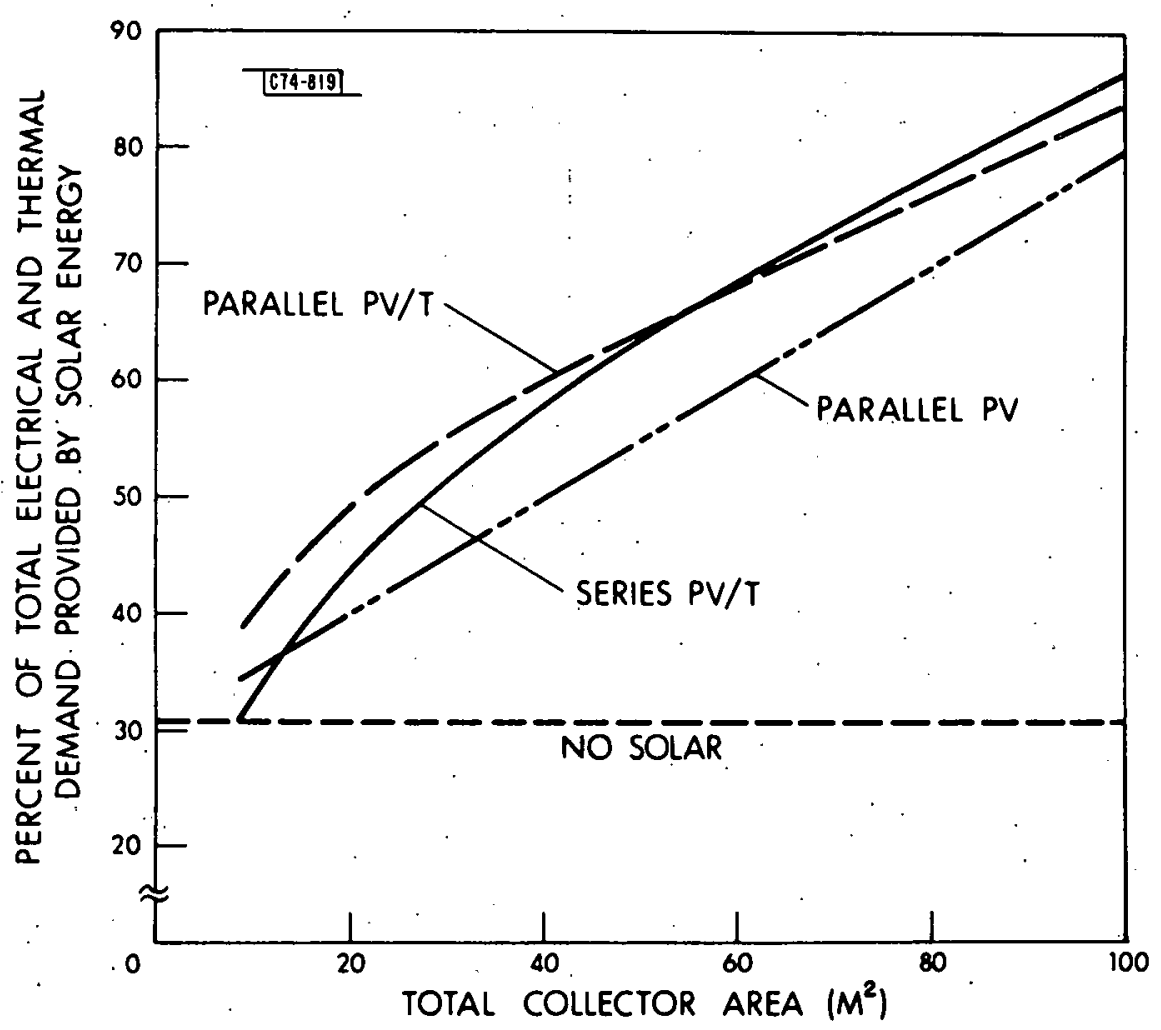

Fig。20. Fort Worth residence system performance results. 
Table 9 lists the percent solar for the parallel heat-pump system using separate photovoltaic and thermal collectors. For a fixed total collector area, the systems utilizing combined photovoltalc/thermal collector systems provide a greater percentage of the total load than any of the separate photovoltaic-combined photovoltaic/thermal collector systems.

TABLE 9

ENERGY PERFORMANCE OF A FORT WORTH RESIDENCE

UTILIZING SEPARATE PHOTOVOLTAIC AND THERMAL COLLECTORS

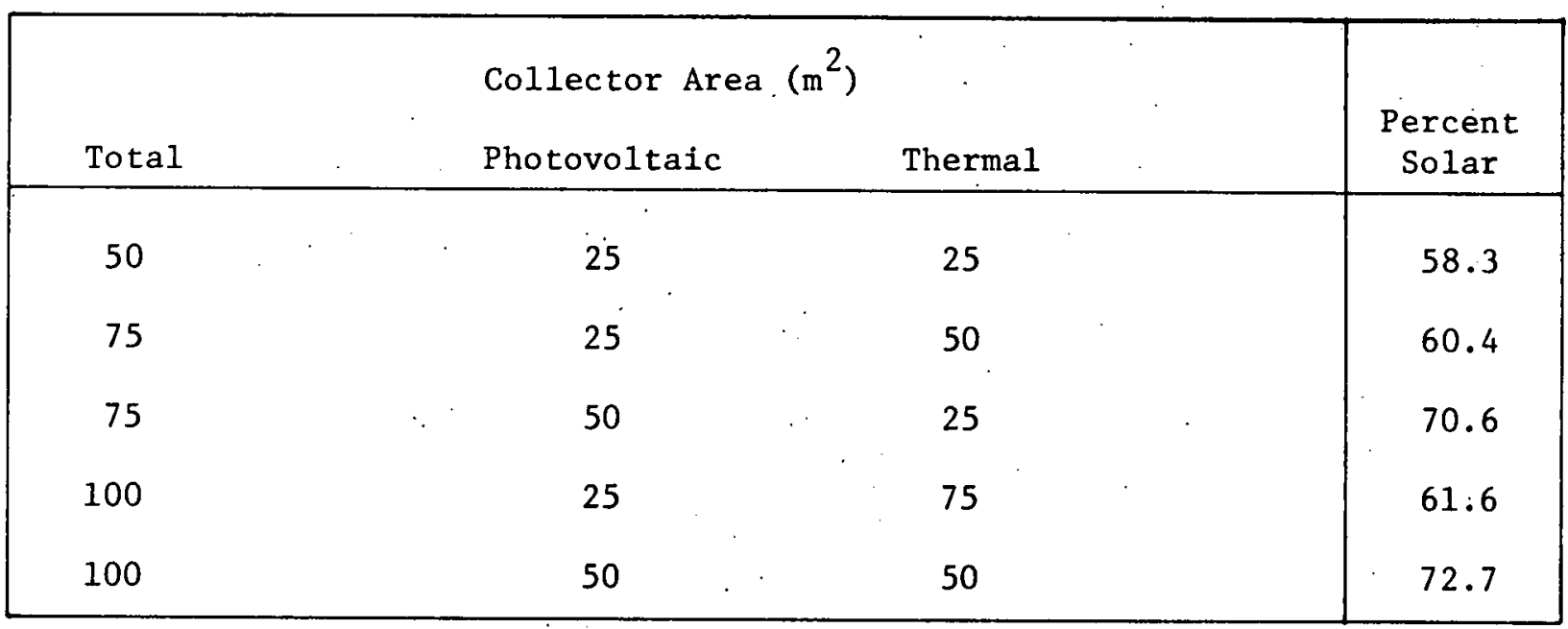

\subsection{Fort Worth Residence System Economic Forecasts}

The economic forecasts for three Forth Worth residential systems are shown in Figure 21. The most economical system option in this location is a parallel heat-pump system with approximately 35 square meters of photovoltaic collectors. This system is the only one which results in a lower annual cost than a conventional non-solar system. The relatively inexpensive time-of-use rate electrical energy prices for the Fort Worth residence (Figure 13) show that all energy used during the heating season is charged at the off-peak rate. The availability of this low-cost electrical energy resulted in no cost-competitive $\mathrm{PV} / \mathrm{T}$ systems for this location.

The economic forecasts for a parallel heat-pump system using separate collectors are given in Table 10. None of these separate collector systems results in a lower than conventional annual cost. 


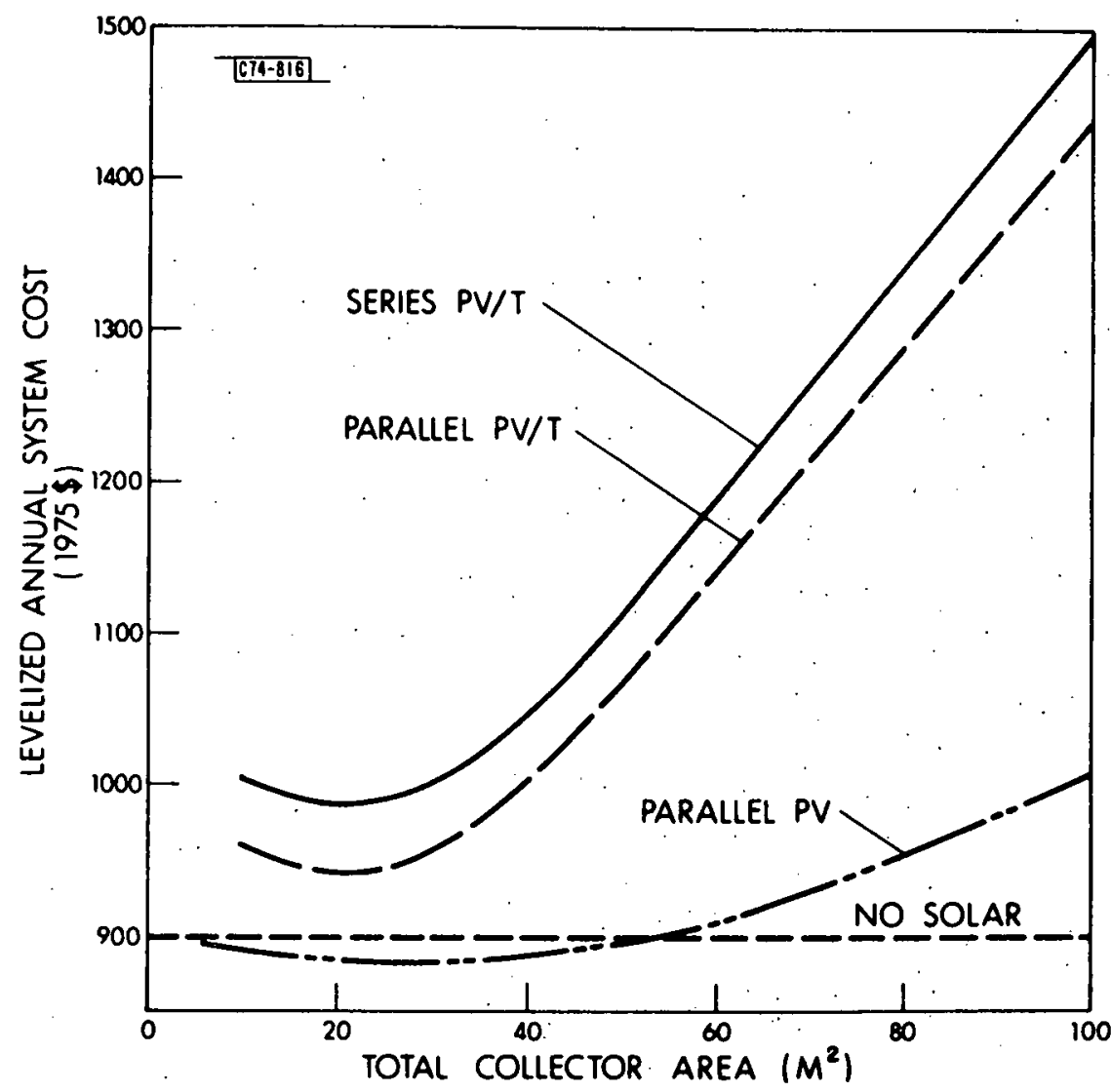

Fig. 21. Fort Worth residence system economic forecasts.

TABLE $\cdot 10$

LEVELIZED ANNUAL COST OF A FORT WORTH RESIDENCE UTILIZING SEPARATE PHOTOVOLTAIC AND THERMAL COLLECTORS

\begin{tabular}{|ccc|c|}
\hline & $\begin{array}{c}\text { Collector Area }\left(\mathrm{m}^{2}\right) \\
\text { Photovoltaic }\end{array}$ & \multicolumn{2}{c|}{$\begin{array}{c}\text { Levelized } \\
\text { Annual System } \\
\text { Cost (1975\$) }\end{array}$} \\
\hline 50 & 25 & Thermal & 938. \\
75 & 25 & 50 & 1069. \\
75 & 50 & 25 & 972. \\
100 & 25 & 75 & 1206 \\
100 & 50 & 50 & 1103. \\
\hline
\end{tabular}


Designs for the most economical solar-energy system for each of the two climate regions have been based upon system-simulation results.

In areas of high utility energy prices and residential heating loads, the most economical energy systems:

- Provide approximately $50 \%$ of the total residential thermal and electrical demands.

- Utilize approximately $4-\mathrm{kW}$ electric peak $\left(40 \mathrm{~m}^{2}\right)$ of combined photovoltaic/thermal solar collectors,

- Or may utilize a combination of separate phitovoltaic and thermal collectors ( $25 \mathrm{~m}^{2}$ thermal, $\left.50-75 \cdot \mathrm{m}^{2} \mathrm{PV}\right)$ for large available roof areas).

- Utilize a utility-interactive DC-AC inverter without on-site electric energy storage.

- Provide auxiliary thermal energy with a parallel heat pump.

In areas where low utility energy prices prevail and heating loads are small relative to large air conditioning loads, the least-cost system option:

- Utilizes approximately $3.5-\mathrm{kW}$ electrical peak $\left(35 \mathrm{~m}^{2}\right)$ of photovoltaic modules.

- Utilizes a utility-interactive DC-AC inverter without on-site storage of electrical energy.

- Provides space cooling and space heating with an ambient-airsource heat pump. 
This Section presents specific hardware recommendations for a prototype residential PV/T system which MIT Lincoln Laboratory will assemble and evaluate for the U. S. Department of Energy. In the process of detailing the conceptual design, additional system configurations were identified, but were not found to warrant consideration. One such system is discussed briefly.

The remainder of the Section describes the commercially available heatpump equipment which most closely meets the requirements of the recommended conceptual system design. The selection between competing manufacturers was usually resolved by schedule requirements. As such, alternative equipment may be available from other suppliers in the near future and no endorsement of the selected equipment is intended or implied.

\subsection{Constraints on System Complexity.}

The series and parallel configurations were considered in detail in Section 2 primarily because of their relative simplicity and because they have been the subject of extensive analyses in connection with exclusively thermal systems (References 3,5, and 6). The results of these analyses are consistent with the results given in Section 3. These previous analyses also show that for exclusively thermal systems, additional system components. (such as a second heat pump or a third refrigerant coll) are not usually economically advantageous. For this reason, the system concepts discussed in section 2.3 were limited to one heat pump, one thermal storage tank, and two heat-pump refrigerant coils.

In order to evaluate the improvements offered by more complex PV/T configurations, the TRNSYS program was applied to the cascade configuration shown in Figure 22. The system's annual coefficient-of-performance was used as a performance index. The cascade configuration is of interest because it reduces to the series, parallel, or dual-mode configuration, provided the appropriate operating procedure is specifled. The dual-mode configuration is sometimes referred to as the three-coil configuration. The cascade configuration can be operated in such a way as to obtain a more favorable annual 


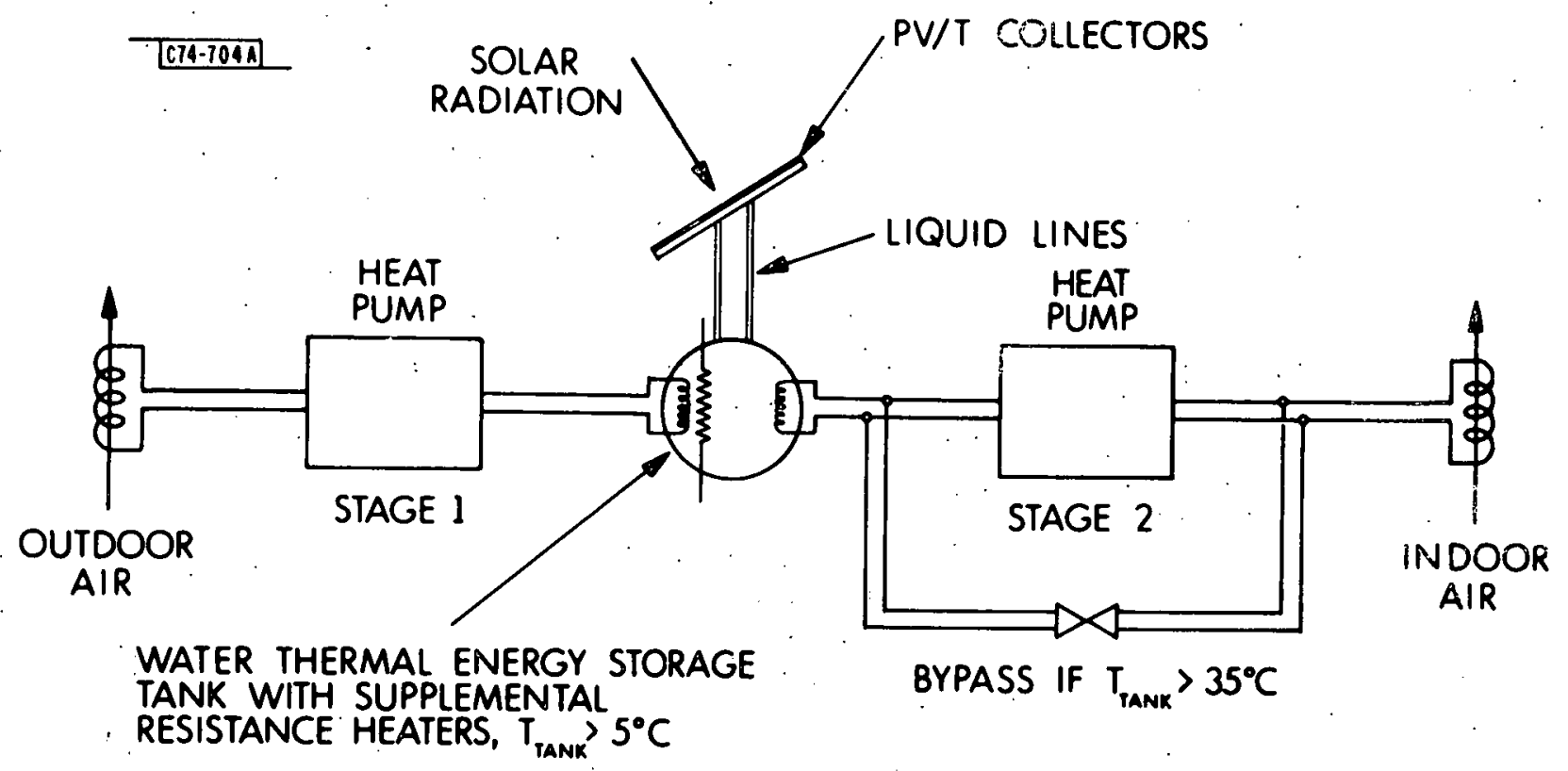

Fig. 22. Two-stage cascade heat-pump configuration.

performance than the series, parallel, or dual-mode configurations. Using a fairly elaborate control strategy and an optimistic assumption concerning the capacity of the stage-one (air-to-water) heat pump, it was found that for the New York. location the annual COP of the cascade configuration was at best only $5 \%$ higher than that of the parallel configuration at all collector areas below $100 \mathrm{~m}^{2}$. Therefore, even if the constraints concerning the number of system components were relaxed; no economic advantage would be gained because of the increased cost of the additional components.

An air-source solar-boosted heat pump in which the evaporator consists of a flat-plate collector is discussed in Reference.7. The flat-plate collector operates near ambient temperature and collects energy either from the ambient air or from solar insolation. This unit is undergoing commercialization as a swimming pool heater. In the residential application, obtaining energy directly from solar insolation requires a thermal storage tank on the condenser side of the heat pump. This thermal storage tank supplies water to heat the return air from the residence and this, water must be warmer than the supply air. Heating the thermal storage tank to a temperature above the residential supply air introduces inefficlencies that are not present in the swimming pool 


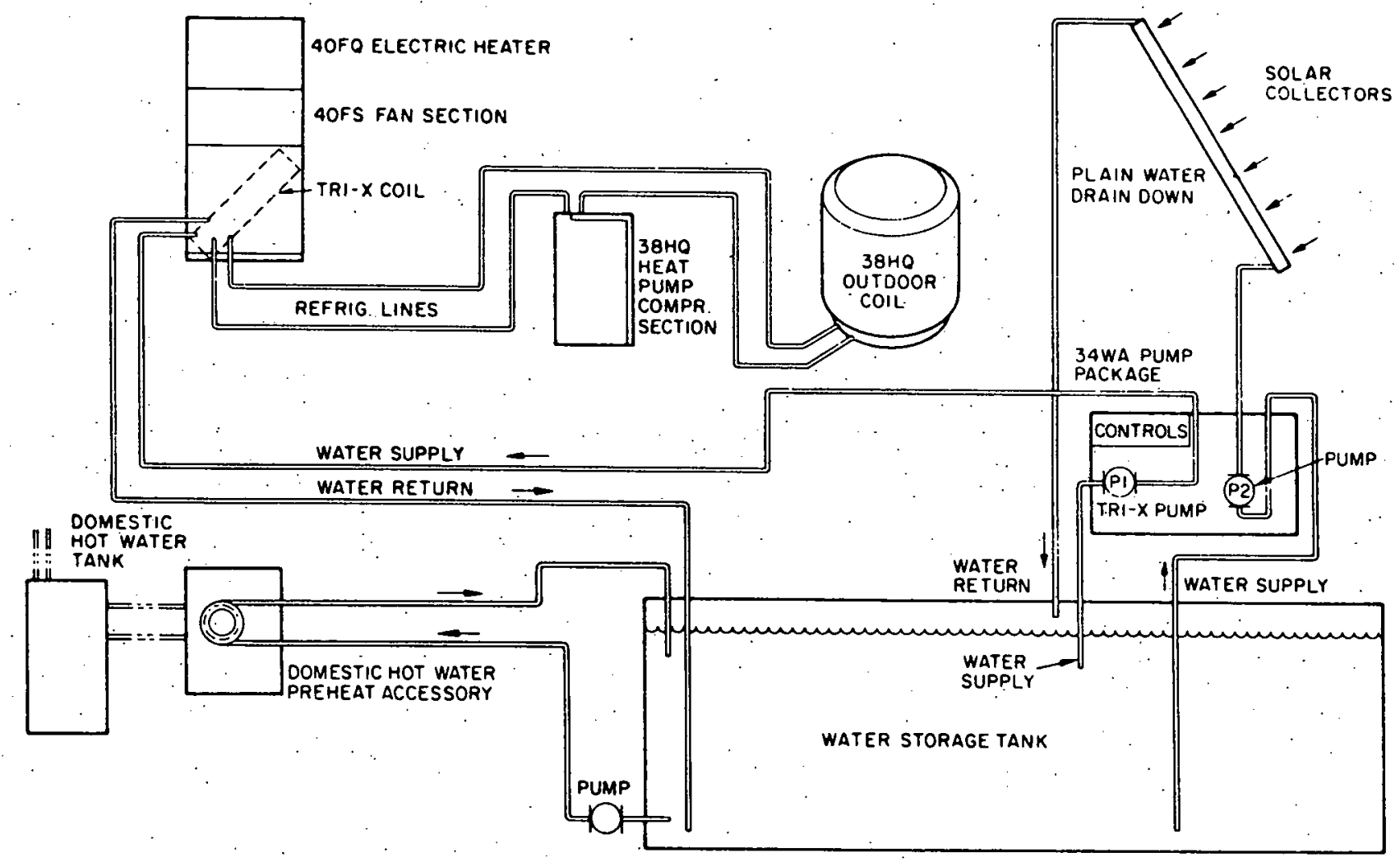

CARRIER CORPORATION'S SOLAROUND SYSTEM

Figure 23. 
application. For this reason inclusion of the evaporator-collector alternative in the residential prototype is not recommended.

\subsection{Hardware Availability and Cost}

An important consideration in the design of a PV/T and heat-pump prototype'system is the availability of the preferred components. Fortunately, this requirement also favors the parallel configuration. Efficient watersource heat pumps suitable for the series configuration are available, but the cost of one of the appropriate units is approximately twice the cost of a two-speed air-to-air heat pump of equivalent capacity. As a result of a recent Department of Energy hardware development contract, the Northrup Corporation has built prototype heat pumps suitable for series and dual-mode operation. However, future availability of this equipment is uncertain. Both Lennox Industries and the Carrier Corporation manufacture two-speed air-to-air heat pumps suitable for use in a parallel system. As yet, only the Carrier Corporation has made available the control and plumbing subsystems that permit effective incorporation of collectors, thermal storage tank, and heat pump into a unified parallel system.

\section{3 Carrier Corporation's "Solaround" System}

The name "Solaround" is a trademark of the Carrier Corporation and is used to designate the combined solar collector and heat-pump system offered by this company (Figure 23). This system is similar to the exclusively thermal parallel systems considered in References 5 and 6 and in Section 2.3.2 of this report. There are, however, some interesting differences that are discussed in the following Sections.

\subsubsection{Variable-Speed Compressor}

Carrier recommends that a single-speed (3500 rpm) heat-pump compressor be used in the Solaround system. The simulations discussed in Sections 2 and 3 of this report confirm that a PV/T system benefits from the availability of a lower compressor speed. For this reason it is recommended that the single-speed heat pump (Carrier series $38 \mathrm{HQ}$ ) be replaced with a two-speed heat pump (Carrier series $3.8 \mathrm{TQ}, 175.0$ and $3500 \mathrm{rpm}$ ). 


\subsubsection{Collector Fluid}

Carrier recommends the use of a Glycol system "... In areas where prolonged periods of subfreezing temperatures occur." The use of Glycol requires an additional heat exchanger and liquid pump. With proper installation, a plain water system is as reliable and efficient even in a northern climate. Proper installation includes fail-safe drain down of the water from the collectors to the storage tank when the circulating pump stops operating. Carrier's recommendation may be based on a concern about the non-uniformity of field installation practices. Both the series and parallel simulations discussed earlier in this report assumed that Glycol was the collector lifquid and that the required additional heat exchanger and liquid pump were present in the system. It is now recommended that plain water be used as the collector liquid in the prototype system.

\subsubsection{Tri-X Co11}

The Solaround system includes an indoor heat exchanger called a Tri-X Coil which accommodates both circulating water and refrigerant in separate tubes. This offers the significant advantage of off-peak cooling of storage water. Not only does this avoid high summer daytime utility rates, but it also permits better humidity control since cooling need not be limited to intermittent heat pump operation. It is undesirable to attempt to control humidity exclusively by direct heat-pump operation unless the capacity of the heat pump and the cooling load are reasonably well matched. Thts is not likely to occur in the case of a northern residence because the heat-pump's capacity will be matched to the winter heating load.

The Tri-X Coil also makes it possible to heat the residence simultaneously, using stored thermal energy along with energy delivered by the heat pump. As pointed out in.Reference 6, this improves the system's annual coefficient-ofperformance provided the temperature of the circulating water does not fall too far below the cut-off temperature for heating exclusively.from stored thermal energy. This" "boosting" of the heat-pump's output will probably be consequential whenever it permits the heat-pump's compressor to remain operating at low speed. This boosting procedure was not incorporated in the simulations 
discussed in Sections 2 and 3. The aiternative of preheating the indoor return air by using stored thermal energy is considered in detail in Reference 6. The configurations examined in this Reference are shown in Figures 24 , 25, and 26. In each case there are twoaalternatives for preheating: (1) using collector fluid (in this case, water) immediately after it returns from the collector, and (2) using water from the thermal storage tank. In Reference 6 , it was found that preheating is a desirable option for all configurations, and that the first alternative is preferred except in the case of the parallel configuration. Before actually incorporating a separate preheating coil in the PV/T prototype system, it is advisable to carry out tests to determine if the Tri-X Coil functions adequately as a booster coil when hot water is circulated through it.

Fig. 24. Series heatpump configuration with preheating of return air.

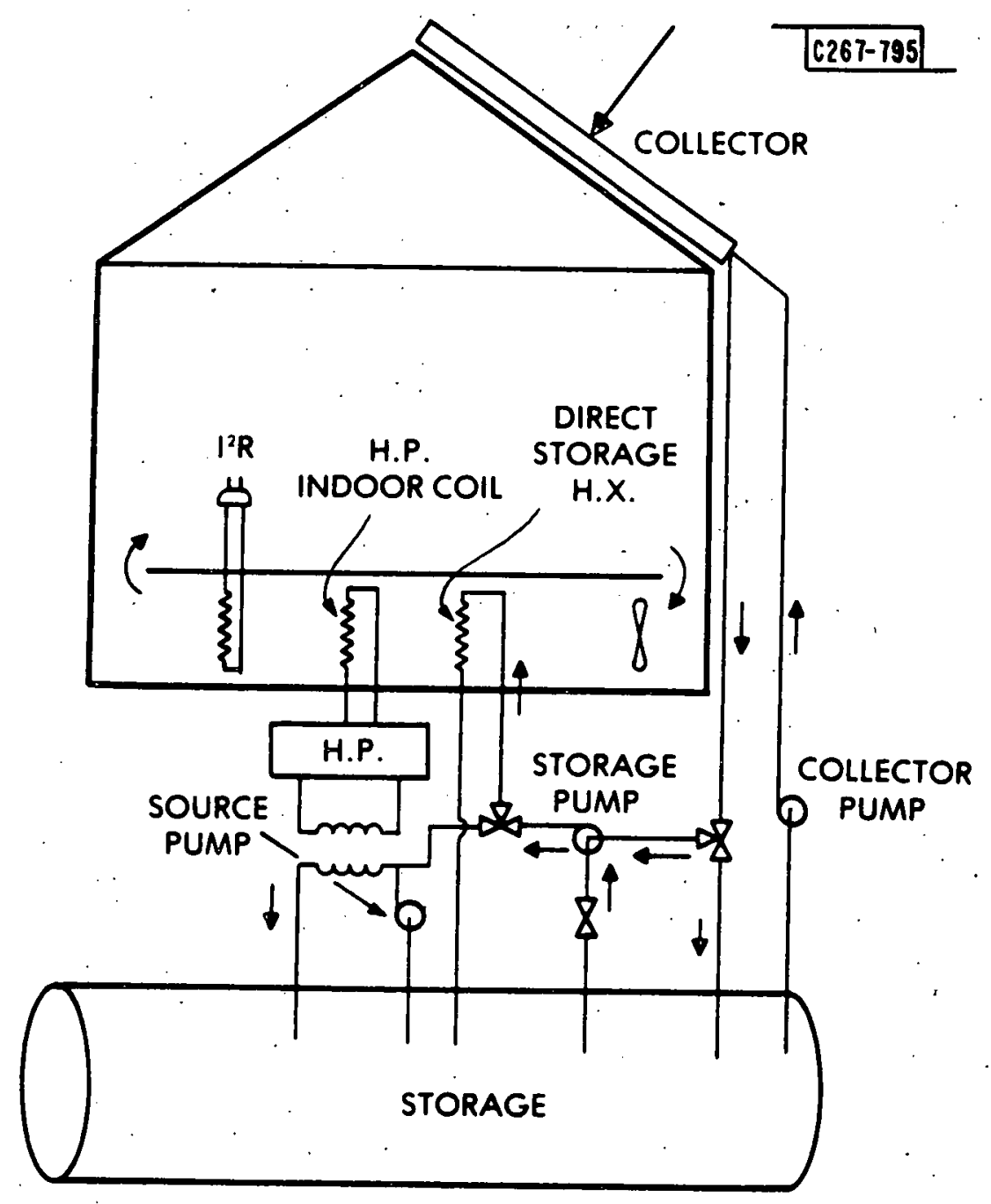




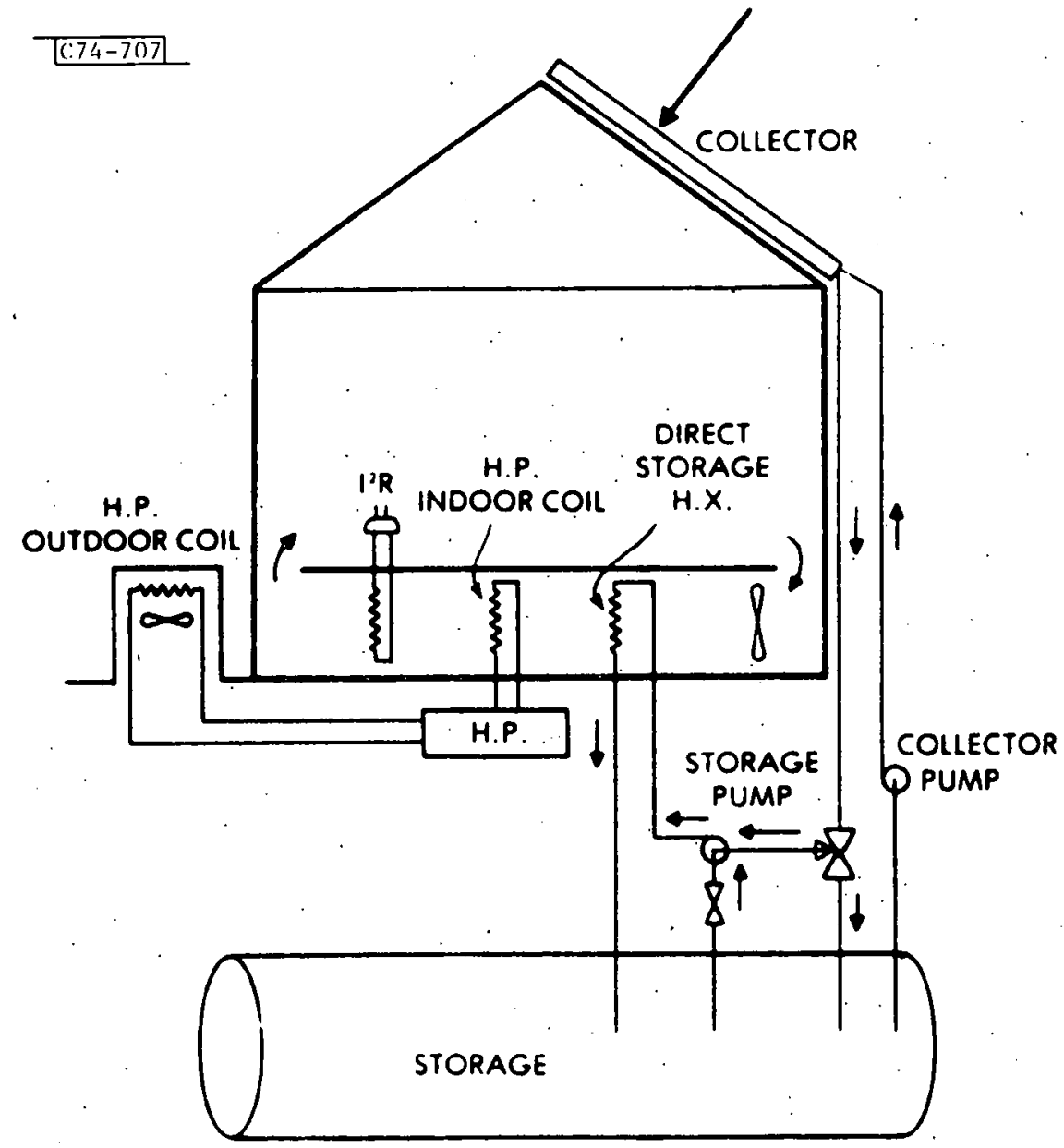

Fig. 25. Parallel heat-pump configuration with preheating of return air.

5.3.4 Desuperheating of the Compressor's Discharge Line

The Solaround system does not contain a heat-pump heat-reclamation device, or desuperheater, for heating domestic hot water. A desuperheater has not been included in previously published analyses of thermal systems, and was not included in the analyses discussed in Sections 2 and 3 . The reason for this omission is that the coding of the TRNSYS computer program does not currently accommodate desuperheating devices and sufficient data describing their performance has not been available. A desuperheater will be incorporated in the prototype $\mathrm{PV} / \mathrm{T}$ system because these devices can reclaim heat equal to between ten and fifteen percent of the energy throughput of the heat pump.

\subsubsection{Resistance Heating}

It is advantageous to install a low-watt density resistance heater in 


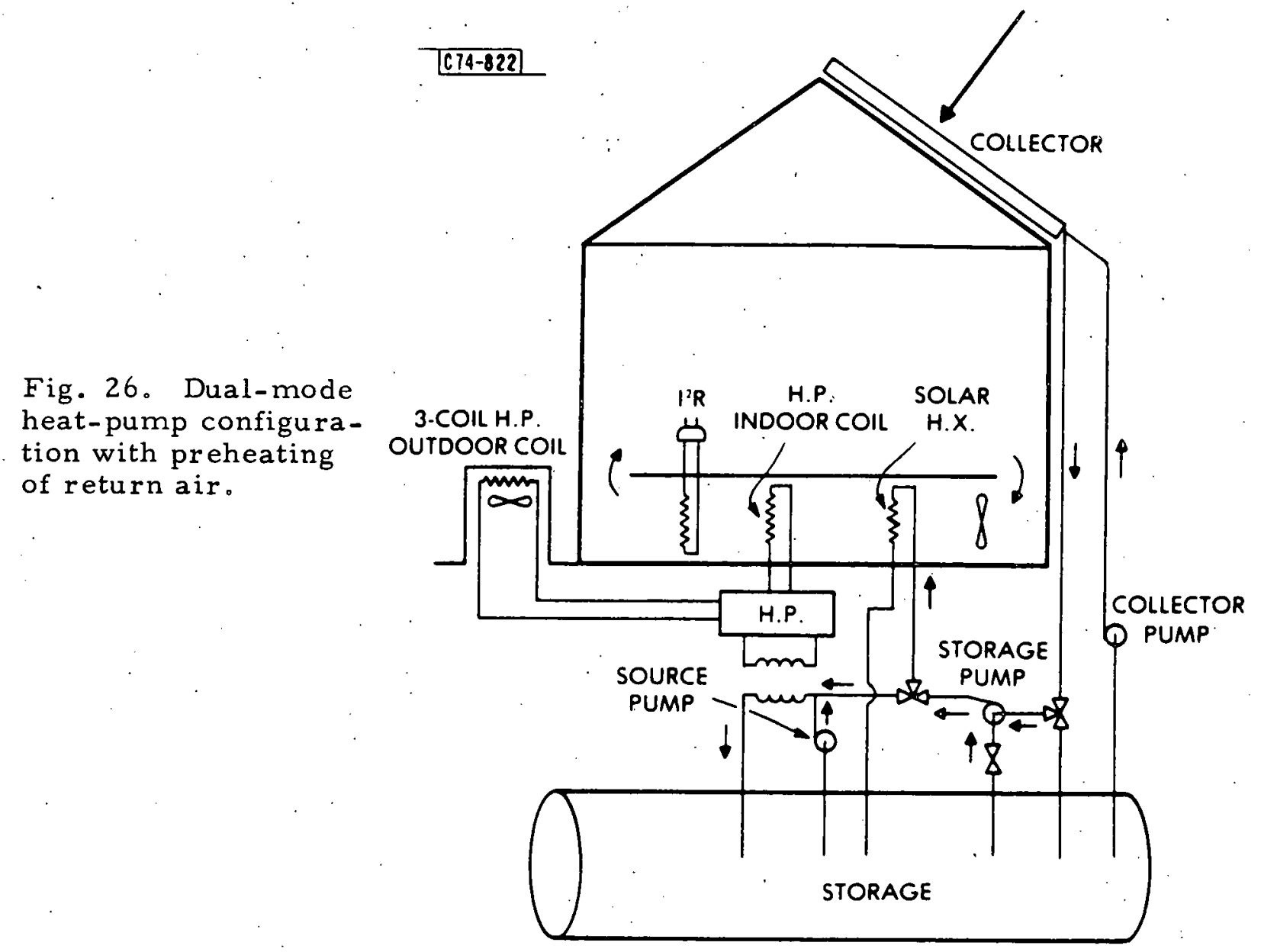

the water storage tank if surplus electric power cannot be directed into the utility grid under favorable terms. The simulations discussed in Sections 2 and 3 assume different sell-back credits and resistance heating of the water storage tank was not considered.

\subsection{Modified Solaround System Inventory}

The Carrier Corporation components listed in Table 11 will be included in the prototype $\mathrm{PV} / \mathrm{T}$ system. The remaining components required by the Solaround system are included in Table. 12. An important requirement of the water storage tank is that it be able to withstand water temperatures as high as $93^{\circ} \mathrm{C}$. A fiberglass-relnforced plastic tank is recommended; the lining of the plastic tank must conform to NBS Product Standard No. PS 15-69. 
TABLE 11

CARRIER CORPORATION COMPONENTS INCLUDED IN

PV/T PROTOTYPE SYSTEM

\begin{tabular}{|lc|}
\hline \multicolumn{1}{|c|}{ Component } & $\begin{array}{c}\text { Carrier Corporation } \\
\text { Part Number }\end{array}$ \\
\hline Heat-pump two-speed compressor section & $38 \mathrm{TQ}-040-301$ \\
Heat-pump outdoor heat exchanger & $38 \mathrm{HQ}-960-301$ \\
Tri-X indoor heat exchanger & $28 \mathrm{QX}-042-001$ \\
Indoor fan section & $40 \mathrm{FS}-200-311$ \\
10-kW indoor resistance heater & $40 \mathrm{FQ}-920-121$ \\
Heat-pump desuperheater & $38 \mathrm{HQ}-900-011$ \\
Thermostat package & $34 \mathrm{WA}-900-011$ \\
Off-rate cooling control & $34 \mathrm{WA}-900-021$ \\
Domestic hot water preheat accessory & $34 \mathrm{WA}-900$ \\
Heat-pump stand & $38 \mathrm{RQ}-900-061$ \\
Filter dryer & $38 \mathrm{CQ}-900-091$ \\
Moisture eliminator package & $28 \mathrm{GS}-660-023$ \\
Plain water pump package & $34 \mathrm{WA}-367$ \\
\hline
\end{tabular}

TABLE 12

REMAINING COMPONENTS INCLUDED IN PV/T PROTOTYPE SYSTEM

\begin{tabular}{|lcc|}
\hline \multicolumn{1}{|c}{ Component } & Manufacturer & Part Number \\
\hline $\begin{array}{l}\text { 80-gallon domestic hot } \\
\text { water tank } \\
\text { 1000-gallon water storage } \\
\text { tank }\end{array}$ & Sepco & E-80-SNR-1-10 \\
PV/T collector array & Owens-Corning & GIMAC \\
Inverter & (to be determined) & \\
& Windworks & $\begin{array}{l}\text { Gemini } 8 \text { kVA } \\
\text { with Max. Power } \\
\text { Tracking }\end{array}$ \\
\hline
\end{tabular}




\subsection{Combined Photovoltaic/Thermal Collectors}

Modifications to current combined photovoltalc/thermal collector designs show promise of improved electrical and thermal performance. Based upon analytical studies and one year of outdoor experimental testing of three prototype PV/T collectors, "second-generation" liquid combined PV/T collectors will be designed and contructed.

The basic liquid-cooled PV/T collector design envisioned incorporates one cover-glass spaced above PV cells which are bonded to an integral absorber heat exchanger. A PV/T collector of this design may be optimized by following the specific design recommendations detailed below.

(i) There exists an optimum cell-to-glass air gap spacing for which the thermal-conductance to heat-loss ratio is a minimum. This spacing, however, is critically dependent on the cell-to-glass temperature difference. For a calculated temperature difference of 8 to $17^{\circ} \mathrm{C}$, corresponding to insolation values between 50 to $100 \mathrm{mw} / \mathrm{cm}^{2}$, a cell-to-glass air-gap spacing of $1.5 \mathrm{~cm}$ is optimum.

(ii) Thermal losses through the collector-top cover glass are typically made up of $60 \%$ radiative losses and of $40 \%$ convective losses. The convective losses may be reduced by a series of crisscrossing grooves on the top glass cover. These grooves enhance the formation of recirculation zones in the ambient air flowing over the glass surface and therefore reduce the effective convective-heat-transfer coefficient.

(1i1) The thermal resistance between the cells and the absorber plate must be kept as small as possible. This can be done by minimizing the electrical insulation thickness between cells and the absorber plate, taking care to avoid air gaps. The traditional insulation, silicone pottant, has a thermal conductivity, $\mathrm{K}$, of 0.002 watts $/ \mathrm{cm}^{\circ} \mathrm{C}$. However, several high thermal conductivity, high di-electric strength, epoxies are avallable with $\mathrm{K}$ ranging from 0.008 to 0.016 watts $/ \mathrm{cm}^{\circ} \mathrm{C}$. Use of these epoxies in place of the silicone pottant would ensure a low thermal resistance between the cells and the thermal collector while insuring electrical isolation. 
(iv) Heat resistance resulting from air gaps between the absorber plate and the liquid-carrying tubes can be minimized by making the tubes an integral part of the absorber plate. One such commerclally avallable absorber plate design is referred to as a "Roll Bond" absorber plate. A rectangular section for these tubes, with a width-to-height ratio greater than 3 , has a higher heat-transfer coefficlent than a circular tube. The larger this ratio, the higher the heat-transfer coefficient.

(v) In the prototype PV/T collectors, the 11quid flow is laminar. For higher heat transfer between the tube and liquid, the flow should be turbulent. Presuming a rectangular tube section, wires on the tube walls normal to the flow can be used to trip the laminar flow to turbulent-flow. Further, the tube walls can be made rough to augment the heat transfer.

A variety of other devices of uncertain cost effectiveness could be used to enhance the transmission and absorption of Insolation by the components of the collector. These include, 1) sitippled top-glass surface to reduce reflection losses, 2) anti-reflectlve coating of bismuth oxide and magnesium oxide on the glass cover and 3) selective paint coatings for the thermal collector plate. 


\section{REFERENCES}

1. "Detached Family House Load Tape," Available from National Bureau of Standards, Washington, DC 20234.

2. Chobotov, V. and Siegel, B., "Analysis of Photovoltaic Total Energy Systems for Single-Family Residential Applications,". The Aerospace Corporation, ATR-78 (7694-02)-1, August 1978.

3. Andrews, J. W., Kush, E. A., and Metz, P. D., "A Solar-Assisted Heat Pump System for Cost-Effective Space Heating and Cooling," Brookhaven National Laboratory, BNL 50819, March 1978.

4. Evans, D. L., Facinelli, W. A., and Otterbein, R. T., "Combined Photovoltaic/Thermal System Studies," Arizona State University, Sand78-7031, August 1978.

5. Freeman, T. L., Mitchell, J. W., and Andit, T. E., "Performance of Combined Solar-Heat Pump Systems," Solar Energy, Vol. 22, pp. 125-135, 1979.

6. Jaster, H., et al., "Solar Assisted Heat Pumps for the Heating and Cooling of Buildings," work performed under Contract No. EG78-C-03-1719 for the Department of Energy, General Electric Company, November 1978.

7. Charter, W. W. S., "Some Performance Characteristics of the Unimeld Air Source Solar Boosted Heat Pump System," 1979 ISES Conference, Atlanta, Georgia, May 1979. 